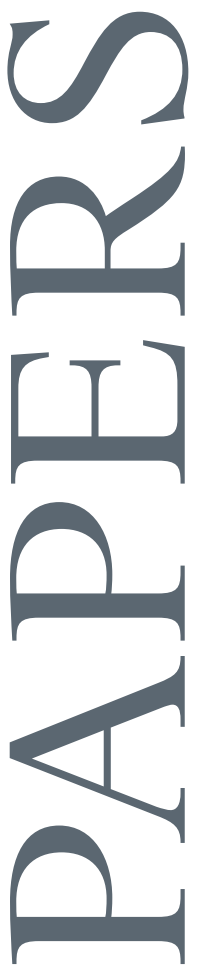

EAST-WEST CENTER WORKING PAPERS

Innovation and Economic Growth Series

No. 3, March 2015

\title{
Myanmar: Cross-Cutting Governance Challenges
}

\author{
Cullen Hendrix and Marcus Noland
}

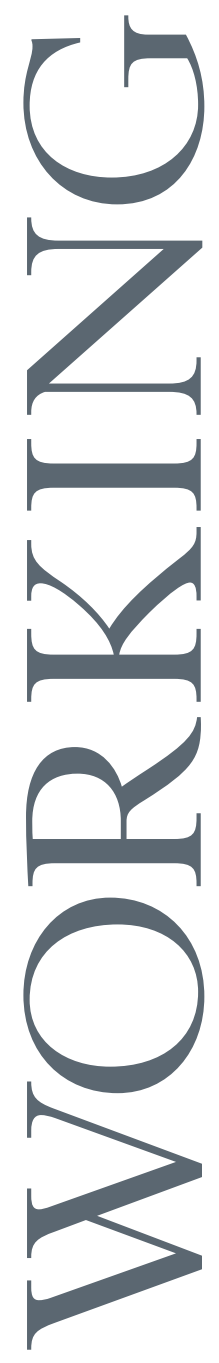

VE $\frac{\text { E A S T - W E S T C E N T E R }}{\text { Collaboration - Expertise - Leadership }}$ 


\title{
Myanmar: Cross-Cutting Governance Challenges
}

\author{
Cullen Hendrix and Marcus Noland
}

East-West Center Working Papers is an unreviewed and unedited prepublication series reporting on research in progress. The views expressed are those of the author and not necessarily those of the Center. East-West Center Working Papers are circulated for comment and to inform interested colleagues about work in progress at the Center.

Working Papers are available online for free at

EastWestCenter.org/ewcworkingpapers.

The East-West Center promotes better relations and understanding among the people and nations of the United States, Asia, and the Pacific through cooperative study, research, and dialogue. Established by the US Congress in 1960, the Center serves as a resource for information and analysis on critical issues of common concern, bringing people together to exchange views, build expertise, and develop policy options.

The Center's 21-acre Honolulu campus, adjacent to the University of Hawai'i at Mānoa, is located midway between Asia and the US mainland and features research, residential, and international conference facilities. The Center's Washington, DC, office focuses on preparing the United States for an era of growing Asia Pacific prominence.

The Center is an independent, public, nonprofit organization with funding from the US government, and additional support provided by private agencies, individuals, foundations, corporations, and governments in the region.

\section{EastWestCenter.org/publications}

Publications Office| East-West Center

1601 East-West Road | Honolulu, Hawai'i 96848-1601

Tel: 808.944.7145 | Fax: 808.944.7376

EWCBooks@EastWestCenter.org
Cullen S. Hendrix, nonresident senior fellow at the Peterson Institute for International Economics, is assistant professor at the Josef Korbel School of International Studies at the University of Denver.

Marcus Noland, executive vice president and director of studies, has been associated with the Peterson Institute since 1985. He is also senior fellow in the Research Program at the East-West Center.

This is a background paper for the Asian Development Bank Myanmar Country Diagnostics Study. We would like to thank Kevin Stahler for diligent and conscientious research assistance, and participants in the ADB workshops, particularly J.P. Verbiest, for helpful comments on an earlier draft. We thank Cyn-Young Park and Winfried Wicklein for their review and comments. 


\title{
Myanmar: Cross-Cutting Governance Challenges
}

\author{
Cullen Hendrix and Marcus Noland
}

\begin{abstract}
Since 2010, Myanmar has been in the midst of a multifaceted transition, involving economic reforms, the resolution of multiple long-standing civil conflicts, and a nascent transition to democratic rule. These transitions are coinciding with a resource-led economic boom. We assess the current status of governance institutions, as well as their performance in comparison to ASEAN and selected other countries. Specifically we discuss outstanding problem areas related to economic governance, particularly in the legal system, the business regulatory framework, and bureaucratic capacity, as well as the potential use of external policy anchors, particularly in the Extractive Industries Transparency Initiative (EITI) process, to strengthen Myanmar's ongoing reform effort.
\end{abstract}

JEL: N45, P28, D72, D73

Keywords: Myanmar, governance, economic reform, resource curse

Cullen S. Hendrix, nonresident senior fellow at the Peterson Institute for International Economics, is assistant professor at the Josef Korbel School of International Studies at the University of Denver. Marcus Noland, executive vice president and director of studies, has been associated with the Peterson Institute since 1985. He is also senior fellow in the Research Program at the East-West Center. They are coauthors of Confronting the Curse: The Economics and Geopolitics of Natural Resource Governance (2014).

Authors' Note: Background paper for the Asian Development Bank Myanmar Country Diagnostics Study. We would like to thank Kevin Stahler for diligent and conscientious research assistance, and participants in the ADB workshops, particularly J. P. Verbiest, for helpful comments on an earlier draft. We also thank Cyn-Young Park and Winfried Wicklein for their review and comments.

(C) 2014 Asian Development Bank. All rights reserved.

This Working Paper is an advance version of a paper that will be included in a future publication by the Asian Development Bank. The views expressed in this publication are those of the authors and do not necessarily reflect the views and policies of the Asian Development Bank (ADB) or its Board of Governors or the governments they represent. When reporting or citing this paper, the authors' names should always be stated explicitly. ADB does not guarantee the accuracy of the data included in this publication and accepts no responsibility for any consequence of their use. By making any designation of or reference to a particular territory or geographic area, or by using the term "country" in this document, ADB does not intend to make any judgments as to the legal or other status of any territory or area. ADB encourages printing or copying information exclusively for personal and noncommercial use with proper acknowledgment of ADB. Users are restricted from reselling, redistributing, or creating derivative works for commercial purposes without the express, written consent of ADB.

For inquiries, please contact:

Asian Development Bank

6 ADB Avenue, Mandaluyong City

1550 Metro Manila, Philippines

Tel +6326324444

Fax +6326362444

www.adb.org

adbpub@adb.org 


\section{Introduction}

Since 2010, Myanmar has been in the midst of a multifaceted transition, involving economic reforms, the resolution of multiple long-standing civil conflicts, and a nascent transition to democratic rule. These transitions are coinciding with a resource-led economic boom, and all the blessings and challenges such booms entail. Taking place in parallel, the outcomes of each transition are interdependent, contingent on the outcomes of others. These transitions provide a unique opportunity to engage in broad governance reform and develop the institutions necessary for a growing economy. The uneven progress on these issues since 2011 simply underscores that success is by no means preordained.

Good governance, or efficient and transparent conduct of public affairs and management of public resources, is close to a necessary condition for long-term economic growth. Governance is an inherently multifaceted concept that encompasses both formal rules and norms governing the conduct of public affairs. Broadly speaking, it can be broken into three basic baskets: the legal and regulatory framework, bureaucratic and administrative capacity, and government transparency/engagement with civil society. While policy is obviously important, good governance is much more fundamental to economic development than any specific policy intervention. Good governance can be thought of as the creation of an environment in which beneficial policy can be formulated and implemented in a socially inclusive manner.

Without good governance, countries fail to unlock the full potential of their human and natural capital. For society to make productive investments in human and physical capital, it needs assurances that these investments will not be expropriated — directly or indirectly — and that contracts will be enforced by independent, nonpartisan courts, even when it is not in the short-term interest of the government for them to do so. ${ }^{1}$ Moreover, these assurances are particularly valuable for courting investment from firms in developed countries and investment in the nonresource sector, whose development will be crucial for generating nonresource-related exports and employment. For markets to truly flourish, the government must be able to efficiently provide market-sustaining public goods, in the form of transparent market regulation, infrastructure, and enforcement of contracts. For these benefits to be widely shared and promote social inclusion, policies should be crafted in collaboration and consultation with civil society groups.

In this working paper, we assess the state of governance reform in Myanmar and outstanding challenges facing the country's political elites, civil society, and both state-owned and private firms. Section II assesses the current status of governance institutions, as well as their performance in comparison to ASEAN and selected other countries. Section III discusses outstanding problem areas related to economic governance, particularly in the legal system, the business regulatory framework, and in bureaucratic capacity, and provides specific policy recommendations for leveling the playing field between state economic enterprises (SEEs), military-affiliated enterprises, and the private sector. Section IV discusses opportunities to engage civil society in Myanmar's economic governance and the peace process. Section V addresses the potential use of external policy anchors, particularly the Extractive Industries Transparency Initiative (EITI) process, to strengthen Myanmar's ongoing reform effort, before section VI concludes with a brief summary of key policy recommendations.

\section{Cross-National Indicators of Governance}

\footnotetext{
${ }^{1}$ To be clear, the constitution prohibits direct expropriation. However, investors can be indirectly expropriated by changing rules and regulations after the investment has been undertaken. This consideration points to the need for a strong court system to impartially adjudicate such disputes.
} 
In recent years a consensus has emerged on the importance of institutions, governance, and, specifically, transparency for economic development. Challenges in assessing the quality of institutions or governance, or the degree of transparency or corruption, are nontrivial, however. Cross-national surveys have become an important means of benchmarking absolute performance, relative ranking, and direction trends across a variety of relevant metrics. While there may be a "beauty pageant" aspect to this evidence, it likely contains some "true" information and at an absolute minimum can be interpreted as a valid indication of the perceptions of local and outside observers.

One of the immediate difficulties confronting both analysts and policymakers alike is the sheer number of such indicators and their reliance on sometimes overlapping sources of information. Even if these challenges can be sorted out, one still has to prioritize various agenda items and devise actual policy responses.

David Givens (2013) carefully examines a huge number of these indicators to statistically separate redundancy and derive the true new information in each measure, then determines the dimensions of governance that have the biggest impact on growth performance. He finds that measures relating to "market infrastructure" - essentially rule of law and corruption - and "civil liberties"- essentially other dimensions of rule of law plus voice - have the biggest impact on growth, surpassing such influences on growth as international trade and geography.

In this section we review Myanmar's performance on a number of these cross-national surveys of governance, focusing on rule of law and the extent of corruption. We then link back to these themes in the concluding section on how international initiatives can be used to anchor Myanmar's own efforts to improve performance in these areas. In almost all cases, we benchmark Myanmar's performance against local comparators Cambodia, Lao People's Democratic Republic (Lao PDR), and Viet Nam (together, the CLMV countries).

The bottom line is that Myanmar's economic governance needs improvement on most of these indicators. Evidence derived from Myanmar-based respondents in the World Economic Forum's Global Competitiveness Report survey indicates that financing and governance issues are at the top of the list of obstacles to development (WEF 2014). ${ }^{2}$ However, some improvement in recent years is evident in the data, reinforcing the notion that the country's recent reforms are being recognized around the world. These results also underscore a basic lesson: Myanmar has nowhere to go but up, and as its institutional practices converge on global norms, we can expect to observe a concomitant reduction in the risk premium associated with doing business in Myanmar, increased foreign investment on better financial terms, and an overall acceleration in growth and improvement in outcomes. In the final section we discuss some specifics of how external policy anchors can be leveraged to further this effort.

We start by examining how local market participants evaluate their own environment. Figure 1 reports Myanmar respondents' ranking of the WEF's "most problematic factors for doing business," a mixture of institutional, policy, and economics fundamentals challenges (WEF 2014). The top five most problematic factors are access to financing (18.0), corruption (13.9), inefficient government bureaucracy (9.7), inadequately educated workforce (8.7), and policy instability (8.6). Following these are inadequate supply of infrastructure (7.1), foreign currency regulations (6.2), tax regulations (4.8), inflation (4.0), government instability/coups (3.8), poor work ethic in the national labor force and restrictive labor regulations (both 3.8), tax rates (3.3), insufficient capacity to innovate (2.1), crime and theft (1.6), and poor public health (0.6). In short, in a substantial sample of Myanmar's businesspeople, governance

\footnotetext{
${ }^{2}$ The 2014-2015 WEF Global Competitiveness Report survey was based on 13,264 valid responses, administered through more than 160 partner institutions worldwide. (The Myanmar partner institution was the Centre for Economic and Social Development of Myanmar Development Resource Institute (MDRI-CESD).) The median country sample size was 87 responses. Myanmar had 86 respondents.
} 
issues such as corruption and an inefficient bureaucracy are considered among the most serious obstacles to economic advancement.

How does Myanmar stack up in a comparative perspective? Table 1 reports scores on overall government effectiveness for the most recent year available from five sources: the aforementioned Global Competitiveness Report (WEF 2014), the World Bank's Ease of Doing Business index (World Bank 2014a), ${ }^{3}$ the World Bank's Worldwide Governance Indicators (World Bank 2013b), ${ }^{4}$ Freedom House index (Freedom House 2014), ${ }^{5}$ and the Heritage Foundation's Index of Economic Freedom (Heritage Foundation 2014). ${ }^{6}$ Table 1 shows that the CLMV countries generally score below the 50th percentile on these indicators, with Viet Nam exhibiting the strongest performance. Myanmar's percentile ranks are 6.9 percent on the WEF overall competitiveness indicator, 6.3 percent on the World Bank's Ease of Doing Business index, 3.8 percent on the World Bank's government effectiveness rank, 9 percent on the Heritage Foundation's overall economic freedom indicator, but it scores 14.2 percent on the Freedom House index. The country shows modest improvement in recent years in absolute terms on both the Freedom House measure (figure 2) and the Heritage Foundation Index of Economic Freedom (figure 3).

These indicators are quite broad and include factors beyond economic governance narrowly defined. Research indicates that rule of law and corruption are particularly salient to long-term growth performance and we concentrate on these dimensions of governance. Table 2 summarizes data on the commercial legal systems of the CLMV countries. The first indicator is the World Bank rule of law measure; it is a composite designed to capture perceptions of the extent to which agents have confidence in and abide by the rules of society, in particular with respect to contract enforcement, property rights, the police, and the courts, as well as the likelihood of crime and violence. The second indicator is a more narrow measure of judicial independence: the country's score on the question "In your country, to what extent is the judiciary independent from influences of members of government, citizens or firms?" The next four indicators address more narrow issues of commercial law: efficiency of dispute settlement, efficiency of the legal system in handling challenges to regulation, cost of enforcing contracts, and cost of resolving insolvency.

Myanmar scores relatively low on the World Bank's rule of law indicator and just above the lowest decile on the WEF's dispute settlement and challenging regulations indicators. Anecdotal evidence suggests that investors complain about uncertainties about the rule of law and sanctity of contracts

\footnotetext{
3 The World Bank's Ease of Doing Business index is based on indicators that reflect a mix of analysis of laws and regulations and subjective assessments by local experts. It is implemented through more than 9,600 local representatives and partner institutions. The data refer to conditions in each country's largest business city and may not be representative of the country as a whole.

${ }^{4}$ The World Bank's Worldwide Governance Indicators are based in information compiled from 30 existing data sources including surveys of households and firms; commercial business information providers, including the Economist Intelligence Unit, Global Insight, and the WEF's Global Competiveness Report; nongovernmental sources, including Global Integrity, Freedom House, and Reporters without Borders; and public sector sources such as the European Bank for Reconstruction and Development's Transition Report. The inclusion of the WEF and Freedom House is a reminder that indices may share underlying data sources, meaning that their apparent consistency may be partly illusory. Conversely, divergences might point to fragility in these indices.

${ }^{5}$ Freedom House is an American nongovernmental organization (NGO) that reaches its findings through "analysis and evaluation by a team of in-house and consultant regional experts and scholars" (www.freedomhouse.org/report/freedom-world2013/methodology [accessed on September 20, 2013]).

${ }^{6}$ The Heritage Foundation's Index of Economic Freedom is a summary measure based on 10 subcomponents. The subcomponents, in turn, are based on a mix of statistical data (tariff levels or tax rates) and indicators derived from sources such as Transparency International and the Economist Intelligence Unit. Specific methodological information is provided on subcomponents cited in subsequent tables.
} 
(McKinsey Global Institute 2013). ${ }^{7}$ Myanmar scores better on the WEF ranking of judicial independence (18.8 percent). Results for the World Bank's enforcing contracts and resolving insolvency indicators are similar, though the country scores close to last place in terms of enforcing contracts (2.1 percent) whereas it sits comfortably above the lowest decile on resolving insolvency (15.4 percent).

Table 3 contains seven cross-national measures of transparency and corruption. First is the wellknown Transparency International (TI) Corruption Perceptions Index, derived from 13 underlying data sources (Transparency International 2013). This index is followed by the World Bank's control of corruption indicator, the Heritage Foundation's freedom from corruption indicator (which is partly based on the TI index), the WEF diversion of public funds ranking, the WEF irregular payments and bribes ranking (the average score across the five components of the question: "In your country, how common is it for firms to make undocumented extra payments or bribes connected with (a) imports and exports; (b) public utilities; (c) annual tax payments; (d) awarding of public contracts and licenses; and (e) obtaining favorable judicial decisions?"), the WEF favoritism in decisions of government officials rank ("In your country, to what extent do government officials show favoritism to well-connected firms and individuals when deciding upon policies and contracts?"), and finally, the International Budget Partnership's open budget index. ${ }^{8}$

In the past, Myanmar had trailed its local comparators on all seven indicators. However the country noticeably improved on the 2013 TI ranking, surpassing Cambodia. In percentile terms, the country scores better on the WEF's favoritism in decisions of government officials indicator (11.8 percent), the World Bank's control of corruption indicator (11.4 percent), and the WEF's diversion of public funds indicator (15.3 percent). In the case of the open budget index, where Myanmar was tied for last place with two others among 98 countries, recent reforms involving publication and parliamentary discussion of the national budget make the country's improvement in the next survey a virtual certainty. Other ongoing reforms in the areas of transparency and corruption are likely to improve Myanmar's ranking on other indicators as well. Figure 4 shows that the country has made modest absolute gains terms in recent years.

Whatever the "true" information provided by the various measures of governance, any fair reading of these results would indicate that Myanmar does not score very high, generally trailing the three comparators, always in the lowest quartile. There is evidence of small improvements in recent years, however, and with deepening reforms, further advancements in absolute and relative scores can be anticipated. One would expect such developments to translate into improved economic performance in the medium to long term.

\footnotetext{
${ }^{7}$ McKinsey Global Institute $(2013,49)$ observes that "One index [of rule of law, done by International Bar Association Human Rights Institute] based on perceptions prior to when reform began in earnest, ranked Myanmar 172nd of 176 nations on the issue." As implied, Myanmar's absolute score and relative position may improve in the future as reforms take hold.

${ }^{8}$ The International Budget Partnership is a global initiative started by the Center for Budget and Policy Priorities, supported by UKAid and a number of philanthropic foundations. "The [Open Budget] Survey assesses the contents and timely release of eight key budget documents that all countries should issue at different points in the budget process, according to generally accepted good practice criteria for public financial management. Many of these criteria are drawn from those developed by multilateral organizations, such as the International Monetary Fund's (IMF) Code of Good Practices on Fiscal Transparency, the Organization for Economic Cooperation and Development's (OECD) Best Practices for Fiscal Transparency, and the International Organization of Supreme Auditing Institutions' (INTOSAI) Lima Declaration of Guidelines on Auditing Precepts. The strength of such guidelines lies in their universal applicability to different budget systems around the world and to countries with different income levels... The results for each country in the 2012 Survey are based on the 125 -question questionnaire that is completed by one researcher or group of researchers within an organization from the country," typically from academic institutions or civil society organizations, with most of the respondents coming from organizations with a significant focus on budget issues (International Budget Partnership, 2012, 44). The Myanmar partner institution was not listed in the report.
} 


\section{Ongoing Economic Governance Reforms}

Though Myanmar has been a fairly isolated and closed economy for much of its history, it would be incorrect to say that it is unchanging. The country experienced an earlier period of reform in the late 1980s and early 1990s, which included the repeal of the 1965 Law of Establishment of the Socialist Economic System, the promulgation of the Private Industrial Enterprise Law (1990), a limited opening to foreign investment (the Foreign Investment Law, 1988), and the reestablishment of private commercial banks (the Financial Institutions Law, 1990). Together these measures generated a brief period of recovery and growth in Myanmar's economy. However, by the mid-1990s Myanmar's government had partially reversed the nascent reform program (Turnell 2011, Mieno 2013).

In 2011, President Thein Sein launched a wide-ranging and ongoing reform program, covering not only the economy but also internal political issues and foreign relations. The National Human Rights Commission (NHRC) was established (and reorganized in 2014). The NHRC has launched a website, and state media published material specifying the complaint process and necessary documentation. The right to publicly demonstrate (subject to notification) was introduced, and draft legislation on the right of association is under debate..$^{9}$ Application of the peaceful protest law by local authorities has been controversial, however, and in June 2014 amendments were enacted to improve implementation.

Labor legislation (the Trade Union Law, 2011), liberal by regional standards, has been enacted allowing unions, and protecting the employment of workers joining a union or participating in a strike, though activists complain of problems in implementation. As of October 2013, more than 500 basic labor organizations (unions) had been certified and wildcat labor unrest is being transformed into legal strikes.

Censorship has been greatly diminished with the abolition of the Press Scrutiny and Registration Division, private publications have commenced political reporting, and independent newspapers began publication in April 2013 (Steinberg 2013a, Clapp and DiMaggio 2013). As we argue below, the development of civil society and a free press are key aspects of making transparency initiatives like the EITI work.

With respect to more technocratic concerns, a nongovernmental (though state authorized) think tank, the Myanmar Development Resource Institute (MDRI), was established as a reform brain trust. It has a three-part program encompassing economics, law, and security and political affairs. The Social and Economic Advisory Council was subsequently started to advise ministries on the enactment of reforms and implementation.

In a further effort to improve the functioning of government, President Thein Sein has also "established the Public Services Performance Appraisal Task Force to review the operations of all government ministries dealing with the public, cut red tape, streamline decision making, restructure organization where necessary, and change organizational culture to improve the delivery of public services" (Clapp and DiMaggio 2013, page 4). In related moves, he also

- established an anticorruption committee and signed the Anti-Corruption Law (2013),

- initiated the process of joining EITI, with the Centre for Economic and Social Development, the economic wing of MDRI, tasked with serving as the secretariat for the application process; MDRI will need enhanced budgetary support to perform its myriad new roles,

- declared the country's intention to join the Open Government Partnership, a multilateral initiative aimed at securing "concrete commitments from governments to promote

\footnotetext{
${ }^{9}$ Reforms aimed at opening space for civil society are discussed further in section IV.
} 
transparency, empower citizens, fight corruption, and harness new technologies to strengthen governance," 10 and

- constituted a working group in the president's office "to make necessary preparations to meet these standards for transparency, accountability, citizen participation, and technology and innovation" (Clapp and DiMaggio 2013, 4). ${ }^{11}$

Myanmar's fiscal processes, which had been among the most opaque in the world, have opened up (International Budget Partnership 2013). In 2012, the state budget was publicly debated in parliament and published in private newspapers for the first time, and the auditor general "has been given a measure of independence" (McKinsey Global Institute 2013, 14). As a result of this greater openness, the state budget is beginning to change in ways reflecting greater accountability to the public. Expenditures on health and education have risen by 78 and 50 percent, respectively (IMF 2013).

Tax reform has been undertaken. Measures include the "abolition of the profit tax and reduction of the sales tax to 5 percent for most items (down from 90 percent in some cases)" (McKinsey Global Institute 2013, 13). The country has also established a long-term vision, which includes reforming tax administration, moving to a value-added tax, and, in conjunction with multilateral partners such as the International Monetary Fund (IMF), World Bank, and the Asian Development Bank, strengthening fiscal management (IMF 2013). Historically, tax measures were somewhat arbitrarily implemented, and the government has accepted that going forward "all taxation-related orders and instructions be enshrined in legislation" (Vriens and Partners 2013b, 6). In 2014, legislation was enacted with the aims of streamlining administration and broadening the tax base, though the IMF expressed concerns that numerous exemptions reduced the system's revenue generation potential (IMF 2014a). Public records indicate that Myanmar's largest firms have stepped up tax payments (Vriens and Partners 2014).

With respect to external relations, the government enacted the Exports and Imports Law (2012) "to make policies and functions related to exports and imports in line with international norms, and to facilitate exports and imports" (Min and Kudo 2012, 47). The law repeals the Control of Imports and Exports (Temporary) Act (1947), though regulations and directives emanating from that law may remain in force if not superseded by requirements of the new legislation.

The enactment of the Foreign Investment Law $(2012,2014)$ and the Special Economic Zone Law (2013, 2014) signal renewed interest in attracting foreign investment. The new laws include protections against expropriation, and external policy anchors back this law as well. In October 2013 the country joined the World Bank's Multilateral Investment Guarantee Agency, which, through the provision of political risk insurance, even in conflict zones, should increase Myanmar's attractiveness as a destination for investment.

One notable example of opening to foreign investment is the liberalization of the telecommunications sector. Foreign investors have begun establishing services, and cell phone usage is becoming increasingly commonplace. The Telecommunications Law (2013) sets a two-year deadline for the government to establish an independent regulatory body. Two foreign operators were granted licenses in 2014.

Nevertheless, the foreign investment regime is still inadequate and further work remains to be done; for example, the McKinsey Global Institute complains in its report on the outlook for Myanmar's

\footnotetext{
${ }^{10}$ Open Government Partnership, www.opengovpartnership.org/about (accessed on September 27, 2013)

${ }^{11}$ President Thein Sein signed the Anti-Corruption Law with reservations over concerns that its terms did not comply with the United Nations Convention Against Corruption (UNCAC), which Myanmar signed in December 2012. In February 2014, a 15member Anti-Corruption Commission was formed, but as of November 2014 the composition and functioning of this body remain under discussion.
} 
economy that foreign direct investment (FDI) is still restricted in some sectors, and the new law places limits on the ability to repatriate profits (McKinsey Global Institute 2013). The most recent IMF Article IV report observes that these remaining restrictions are minor but should be removed to comply with IMF Article VII obligations, as well as ASEAN Economic Community requirements (IMF 2013). Foreign investment has, to date, been targeted mostly at extractive sectors, which, while growth promoting, tend to employ comparatively small, often imported, labor forces. Diversifying FDI toward light manufacturing and agriculture will be necessary for Myanmar to take advantage of its fertile land and large, working-age population.

\section{Property Rights and Factor Markets}

Myanmar is sometimes described as a "transitional economy" and lumped together with neighbors such as Cambodia, Lao PDR, and Viet Nam. The reality is more complex, however. Private property rights are delineated and nationalization prohibited under the constitution. And unlike its neighbors, nominally private businesses, not state-owned enterprises, are already at the center of the economy. But these entities may reflect deep state connections: They either are former SEEs with implicit expectations of bailouts if they run into difficulties or are simply controlled by politically connected cronies. State influence is more profound than notional figures on private sector activity would suggest.

\section{The Land Market}

The land market remains problematic. Constitutionally, all land is residually owned by the state (Steinberg 2013b). Historically the state or politically connected entities have exercised eminent domain in what some have described as arbitrary "land grabbing." Land ownership registries are inadequate, and as McKinsey has observed, "if disputes arise over land, Myanmar currently has no meaningful recourse and no national legal-aid program to ease access to the justice system" (McKinsey Global Institute 2013, 77). Presocialist era cadaster maps - surveys of land ownership and tenure - have been lauded for comprehensiveness (Binns and Dale 1995) but are likely to be of limited use in establishing current property rights and appropriate valuation. ${ }^{12}$

The land dispute issue is particularly sensitive insofar as the military's prominence in alleged land grabbing. A parliamentary commission calculated that since 1988 the military has seized nearly 100,000 hectares. In June 2013 the press reported that the Minister of Defense Brigadier General Wai Lwin promised to return confiscated land that was not being used, or about 8 percent of the disputed property. There are now disputes over the definition of "use" and claims that the military rushed to construct improvements to demonstrate the land was under use (Vriens and Partners 2013a, 2013b, 2013c). Beyond the obvious commercial stakes, this particular aspect of the land issue is likely to take a long time to sort out, insofar as it turns on the image of the military and its relationship to the broader society, as well as military practices such as requiring soldiers to grow their own food. The government has formed a Central Land Management Committee and set a one-year deadline for resolving 745 targeted disputes.

The Farmland Law (2012), while representing progress, is inadequate. The law allows farmers use rights (though not for the extraction of subsoil minerals). The bill strengthens protections for farmers from

\footnotetext{
${ }^{12}$ In October 2013, the Yangon Region Revenue Department began using fixed appraisal rates to collect taxes on local land transactions. The policy was introduced in part to confront the phenomenon of gross underreporting of sales prices to avoid property taxes, which are linked to the buyer's ability to document his or her income source. Buyers who obtained their income through illicit activities would report transaction prices that could be justified on the basis of licit earnings alone (Vriens and Partners 2013c).
} 
"land grabbing" by private entities, while maintaining the government's right to exercise the principle of eminent domain in exchange for "suitable compensation" (Nehru 2013, 11). In other low-income countries where farmers have been given the right to "permanently transfer" their user rights or the right to sell land, "land ownership concentration has increased dramatically, creating large numbers of landless and exacerbating poverty" (Nehru 2013,11). It is claimed that "Despite the passage of a new land law by the parliament, people in Myanmar are still being unfairly displaced by large businesses and agricultural projects without adequate compensation or means of providing a livelihood. This is largely a legal matter, in which the law itself still allows sizeable tracts of land to be seized" (Clapp and DiMaggio 2013, 11). Ultimately the solution is not simply more efficient legal systems but more systematic programs to ensure that large-scale development projects are adequately inclusive and address the legitimate interests and needs of local residents and that those residents are afforded stable land rights that are not subject to abrogation by politically connected interests. A new draft Land Use Law was unveiled in October 2014.

The use (and misuse) of forest land is also an issue. According to Kevin Woods (2013), Myanmar's timber land can be divided into five categories:

- $\quad$ state-managed (Myanmar Timber Enterprise) forests;

- logging concessions in natural forests, most in ethnic minority populated areas;

- land conversion in natural forests, also occurring in, though not limited to, areas of ethnic conflict;

- a limited number of tree plantations; and

- community forests, where commercial logging is prohibited.

The last category is the only one in which local communities have legal land or resource use rights, and not surprisingly logging activities have been subject to considerable internal controversy. ${ }^{13}$

In this context, the controversy over the Letpadaung copper mine could provide a salutary learning moment. The March 2013 parliamentary commission report, which attempted to address various stakeholder interests, could form a model for other such disputes, calling for "adequate social and environmental safeguards from companies, transparency in the conduct of the project, proper compensation for local people who have been displaced, adequate provisions for their future livelihoods, preservation of local cultural and religious sites where appropriate, and training for local populations to provide the skills needed to work on the project" (Clapp and DiMaggio 2013, 12).

Likewise there are issues with respect to urban or industrial use land. The government has established 18 industrial parks in nine states and regions under the auspices of the Industrial Development Committee chaired by the Minister of Industry No. 2 (Min and Kudo 2012, McKinsey Global Institute 2013). Investors have complained of bottlenecks, however, with regard to lack of available land for industrial development and the high price of unimproved land in these estates (Pun 2012, Min and Kudo 2012). It has been estimated that only 20 percent of the land in the existing zones is currently used for industrial production; the other 80 percent is used for activities such as warehousing or is unused altogether.

To spur industrial development, the state should lease land at competitive rates to anyone who will build a factory and provide employment; the land could revert to the state if the factory closed.

Concurrent with these new leases, the Ministry of Finance and Revenue should conduct a comprehensive land survey - security conditions permitting - in order to establish a current cadaster map of the country's territory and promote transparency in land use and tenure.

\footnotetext{
13 Timber exports are also subject to controversy as taken up below.
} 


\section{The Labor Market}

The state has enacted or is considering a number of major pieces of labor reform legislation. As of September 2013, a minimum wage law is under consideration. The Social Security Law (2012) updates the earlier Social Security Act (1954). The law creates a Social Security Board empowered to provide medical and social care insurance, family support insurance (in case of natural disaster), disability and pension benefits, unemployment insurance, and other social transfer schemes. In coordination with the Ministry of Labor, the board is permitted to establish offices and facilities to deliver these services and benefits. The labor ministry has been instructed to establish the firm size at which these obligations kick in.

The Settlement of Labor Dispute Law (2012) replaces the Trade Disputes Act (1929). It safeguards workers' rights and establishes procedures including conciliation and arbitration for the orderly settlement of labor relations disputes.

The Employment and Skill Development Law (2012) establishes a Central Body for Employment and Skill Development charged with promoting employment and upgrading skills and capacity. The WEF (2014) cites lack of skills in Myanmar's labor force as one of the primary obstacles to the country's economic development.

\section{The Capital Market}

Although efforts are ongoing to establish direct capital markets (and indeed a tiny stock market opened in October 2014), it is safe to assume that for the foreseeable future enterprises in Myanmar will continue to rely primarily on a bank-dominated system of indirect finance.

The banking system consists of four state-owned banks, which have their origins in a monobank system under the socialist regime, and 19 private banks established in the 1990s when the Financial Institutions Law (1990) permitted the creation of private banks (Mieno 2013). There is currently no foreign operational banking presence, though the government is in the process of finalizing regulations that will permit entry via joint ventures with local banks, and some foreign banks have begun establishing representative offices (IMF 2013). The IMF assesses that supervision of local banks lags well behind international standards, including with respect to anti-money laundering. ${ }^{14}$

Many of the local banks are subsidiaries of large conglomerates. Such an arrangement, where industrial conglomerates own private banks, has proved to be problematic in other settings.

The state-owned banks and private banks each account for roughly half of bank assets. Of the four state banks, Myanmar Economic Bank is by far the largest, accounting for more than 40 percent of the sector's assets. So in reality, the banking system could be described as a single bank dominant system with a fringe of much smaller competitors.

The system does not appear to do a particularly good job of channeling capital to the private sector, with the share of domestic credit going to the private sector a mere fraction of that observed in Cambodia, Lao PDR, or Viet Nam (IMF 2010, Turnell 2011). Instead, regulations have historically included a ban on private lending to farmers, outmoded quantitative limits on deposit and loan rates

\footnotetext{
${ }^{14}$ The last issue is sufficiently acute that the country has been warned by the multilateral Financial Action Task Force (FATF) that it could face countermeasures that would reverse recent advances in cross-border financial integration. In 2014 an AntiMoney Laundering Law and a related Anti-Terrorism Law were passed to address FATF concerns, but the IMF assesses that "substantial deficiencies remain in the Anti-Money Laundering/Combatting the Financing of Terrorism (AML/CFT) regime" (IMF 2014a, 14).
} 
implying negative interest rates, a ban on the provision of uncollateralized credit, a ban on "at call" deposits, which are used to manage liquidity in most other banking systems, and a ban on deposit withdrawals from the Myanmar Agricultural Development Bank (MADB), which unsurprisingly discourages new deposits, discouraging the effective intermediation of savings and formal sector financial deepening beyond a narrow stratum of participants.

The situation is changing, however. The IMF reports that the country's eligible collateral has been expanded to include agricultural exportables; deposit rates have been liberalized within a fixed band; and the MADB has increased credit limits to farmers. The banks are opening more branches, and new technologies such as credit cards and automated teller machines are being introduced. Therefore, access to banking, at least for the urban middle class, appears to be improving.

Apart from the debilitating effect that the atrophied state of the banking sector has on development, the lack of financial inclusion could contribute to undesirable long-term political economy developments. Groups either with access to capital outside the local banking sector, notably the ethnic Chinese minority, or with privileged access to finance, such as the military, may come to dominate the private sector economy and the emergent middle class. Such a development and its implied blunting of socio-economic mobility could become a source of tension (Steinberg 2013a, 2013b).

In sum, as one analyst observes, "Despite the dramatic expansion of private sector banks in Myanmar, they still remain the private 'asset managers' of particular conglomerates and do not yet appear to function as effective financial intermediaries in the national economy. There is obviously room for further development in the efficient functioning of financial intermediaries in Myanmar" (Mieno 2013, 113-14).

In August 2014 nine foreign banks were issued licences to operate. The licences require $\$ 75$ million investment and restrict the foreign banks to a single branch lending only in foreign currencies to foreign companies and local banks. In the words of one commentator, "the restrictions are aimed both to protect the local financial services sector and to encourage the transfer of knowledge and best practices by encouraging foreign-local cooperation" ${ }^{\prime 15}$, and the on-lending to local banks may create a potential for local firms to access foreign banks through syndicated loans (Turnell 2014).

\section{Corporate Governance}

Given the state domination of the financial sector and the ubiquity of SEEs and politically connected enterprises in the economy, corporate governance in Myanmar has been historically problematic. The basic issue is that the SEEs were not subjected to hard budget constraints, and benefitted from capital channeled by the state-dominated banking sector, provisions of subsidies, and dispensation from paying taxes (Kubo 2012). However, recent reforms should mitigate, if not terminate, such practices.

Exchange rate reforms have been important in this regard. Prior to April 2012, the official and unofficial exchange rates diverged markedly, with the official exchange rate implying a much higher value of the kyat than the unofficial rate determined in the market. With the introduction of a managed float in April 2012, the reference rate has converged on the market rate eliminating the implicit subsidization of the SEEs that occurred via the exchange rate mechanism (Kubo 2012, Mieno 2013). (A liberalization of imports has contributed to the subsequent depreciation of the unified rate.) President Thein Sein has proposed that the SEEs stop receiving explicit subsidies and begin paying taxes as comparable private enterprises do. ${ }^{16}$

${ }^{15}$ Dan Gallucci, "Telecoms and banks lead Myanmar reform push,” Financial Times, August 18, 2014.

${ }^{16}$ Win Min, interview at MDRI, May 29, 2013. 
The issue of soft budget constraints is a deeper problem, however. Koji Kubo (2012) argues that the integration of the SEEs into the state budget through the State Fund Account actually worsened the problem, and that resolving the issue requires the abolition of central planning of prices, production, and distribution of goods and services that the SEEs provide. The necessary reforms include the separation of the SEEs from the state budget as well as the abolition of price controls and the implicit cross-subsidies in the state sector" (Kubo 2013, 26). From 2013-14, profitable SEEs are expected to self-finance working capital, while the state will continue to finance 20 percent of the working capital of loss-making SEEs. This change represents a move toward greater financial autonomy for the SEEs insofar as the state financed 78 percent of the working capital of these enterprises previously (IMF 2013).

However, in February 2011, just before the military junta left office, there was a massive privatization of state assets, which some observers likened to a "fire sale" (e.g., Kubo 2013). As a consequence, the soft budget constraint issue may now manifest in a different form, similar to that observed with respect to the government sponsored enterprises at the heart of the 2007-08 financial crisis in the United States. The problem is one of moral hazard, where ostensibly private enterprises engage in risky behavior because they believe themselves to be indemnified against losses due to their political connections. Specifically, the expectation is that these now nominally private enterprises, in many cases controlled by former officials, could seek help from the government after making bad investments, thus increasing the likelihood that bad investments would be made; or, similarly, banks may infer that the government is likely to bail out bad loans made to the former SEEs and thus not scrutinize borrowing carefully. The situation in Myanmar is made worse by the fact that the banks themselves may be connected through ownership to the borrower.

Moreover, the simple privatization of such entities without any regulatory oversight may create the conditions for implicit monopolies, oligopolies, and rampant rent seeking. Such developments may become particularly pernicious in the nontraded sector, as the external opening of the economy and integration into ASEAN bring greater competition to the relatively undeveloped traded-goods sector and indigenous, more politically connected entrepreneurs retreat to the comparative safety of the nontraded sector.

\section{Bureaucratic Capacity}

Both survey-based indicators of government effectiveness and official government revenue statistics suggest Myanmar's bureaucracy is in need of reform and significant capacity building. The World Bank's Worldwide Governance Indicators place Myanmar in the fourth percentile in terms of government effectiveness, which captures "perceptions of the quality of public services, the quality of the civil service and the degree of its independence from political pressures, the quality of policy formulation and implementation, and the credibility of the government's commitment to such policies" (Kaufman, Kraay, and Mastruzzi 2010,4). Revenue-generating capacity is another often-used measure of bureaucratic/administrative capacity, as revenue collection requires the development of significant infrastructure and human capital for collecting and managing information. Total government revenues in 2011 were estimated at only 12 percent of gross domestic product (GDP), compared with a mean of 20.4 percent for the ASEAN-5 countries (Indonesia, Malaysia, the Philippines, Thailand, and Viet Nam) and 28.1 percent for emerging-market and developing economies (IMF 2014b). Since then, however, revenue collection has increased dramatically, nearly doubling to 22.3 percent in 2013, putting it on par with ASEAN-5 countries (IMF 2014b).

Traditionally, nontax revenue has been low, accounting for only 2.1 percent of GDP (OECD 2013), which is quite low in light of the centrality of extractive industries to the economy. Mined 
commodities, especially hydrocarbons, are usually associated with much higher state revenues, as the concentration of production and labor around mines and wells - including offshore platforms-constitutes a natural tax handle, or bottleneck in the production of a good, which makes evasion inherently difficult. The Myanmar experience is partly a function of the since-reformed exchange rate mechanism and can be expected to be rectified under the new exchange rate regime. ${ }^{17}$ Nevertheless, the low levels of tax collection are also in part due to the design of the tax system but also due to low levels of tax compliance and enforcement.

Myanmar is emerging from a 25-year period of military rule, during which the State Peace and Development Council, formerly the State Law and Order Restoration Council, exercised control over all three branches of government. During this period, virtually all of the senior positions in line ministries were staffed by generals and retired military officers. The military penetrated into the lower levels of bureaucracy as well, after many civilian bureaucrats were sacked because they participated in antigovernment protests in 1988 . These positions were often given to regional military commanders who were folded, in large numbers, into the central administration.

The militarization of the bureaucracy had three pervasive effects. The first was to produce a highly centralized and assertively top-down form of decision-making and policy implementation. While all bureaucracies are hierarchical in nature, military hierarchies are unique in the degree to which the chain of command is observed. The salient features of chain of command are vertical lines of communication and accountability (orders flow down, feedback flows up), strict observance of orders, and noninterference in other units. Each has practical implications for the functioning of line ministries. Chains of command do not reward initiative by lower-level functionaries, who instead rely on top-down direction. Diversity of opinion is considered divisive, rather than potentially innovative. Because information must flow back up through several links in the chain, it can be both distorted (either intentionally or unintentionally) or quashed in order to avoid the appearance of poor performance.

The principle of noninterference in other units hampered interministerial cooperation, as lines of delegated authority were blurred and there was no clear mechanism for producing or carrying out joint policy initiatives. While some ministries appear to collaborate effectively - the Ministry of National Planning and Economic Development and the Ministry of Finance jointly harmonize capital and current budgeting — other areas do not benefit from such collaboration. The Ministries of Energy and Electric Power were, as of 2014, developing separate master planning documents without interministerial coordination. Education policy falls under the purview of at least a dozen different ministries. While the Ministry of National Planning would be a potential agent for policy harmonization across ministries, it has neither budgetary power nor a mandate to do so.

The second result of the militarization of the bureaucracy was the proliferation of ministerial appointments, though also due in part to the pursuit of a centrally planned economy. Myanmar's cabinet is comparatively large, consisting of 30 line ministries. The median for ASEAN countries is 19.5. ${ }^{18}$ There is a general negative relationship between cabinet size and government effectiveness, with a significant deterioration of government effectiveness once the threshold of 20 line ministries is passed (Klimek, Hanel, and Thurner 2009; see figure 5). As ministries proliferate, it becomes more difficult both to achieve collective decisions and to coordinate policy implementation across ministries. Whether this is due to declining efficiency in collective decision-making, increasing transaction costs of coordinating policy at the implementation stage, or both, has not been tested, but it is likely that both play a role. Also,

\footnotetext{
${ }^{17}$ The issue relates to the aforementioned implicit subsidy to SEEs via the old exchange rate mechanism. Royalties and revenues from gas exports entered the budget at the official exchange rate until exchange rate unification, opening up the possibility of all sorts of "leakages" (Kubo 2013).

${ }^{18}$ As of November 23, 2014, per CIA (2014).
} 
more government ministries provide more government jobs and thus more opportunities for staffing ministries as a form of political patronage.

The third result was to homogenize the educational backgrounds and worldviews of mid- and toplevel bureaucrats. Of the 38 current $^{19}$ line ministers and cabinet-level appointments, 23 are former military officers. Many, if not all, were trained at the Defense Services Academy (DSA), which trains future military officers for all three branches of the Tatmadaw. While this service academy is widely viewed as one, if not the, preeminent institution of higher learning in Myanmar, the prevalence of its graduates in ministerial positions implies that most ministers share a common formal training in the natural and social sciences. Whatever its merits, relying so heavily on a single educational institution to staff the bureaucracy risks the stifling of initiative and diversity of opinion. The success of DSA graduates in climbing the ranks of both the military and the bureaucracy contributes to the perceptions that the military is still the most reliable vehicle for advancement in the public sector.

At the subministerial level, resource and staffing constraints are significant. The mandates of multiple ministries have grown much faster than their budgets. Bureaucratic pay remains low, despite salaries having been increased by 20 percent in each of the last two years. Low public sector salaries hamper attempts to recruit "the best and the brightest" and can exacerbate problems with corruption (Van Rijckeghem and Weder 2001). Even though the 2013-14 budget includes a 23 percent increase in public sector wages, this problem is likely to become more significant with the emergence of the private sector and increasing foreign investment (OECD 2013). In 2012, business interests forecast an increase in wages for skilled works of 20 to 50 percent for the next year, with wages for those working for foreign firms potentially even higher. ${ }^{20}$ Nongovernment jobs have become relatively more attractive, making it more difficult for the government to recruit and retain productive workers, especially ministries that rely on highly sought-after technical skills, such as the Ministry of Finance and Revenue, which operates the central bank.

One obvious option is to continue raising wages in the public sector, a strategy successfully implemented by Singapore (Rahman 1986). However, wage increases may not by themselves be sufficient, for several reasons. First, wage increases that would be necessary to stamp out corruption and retain the most effective bureaucrats might be so large as to be impractical: on the order of two to eight times the wages in the manufacturing sector (Besley and McLaren 1993, Van Rijckeghem and Weder 2001). Second, the long-term retention effects of wage increases are likely to be eroded by continued growth in the private sector. Third, given the size of the public sector, across-the-board wage increases could have undesirable inflationary effects. Moreover, general wage increases benefit both highly productive and shirking employees alike and may actually lower morale among the most talented.

Developing-country governments have tried a variety of alternatives to build longer-term allegiance to bureaucratic careers among desirable workers. One possibility would be to train and construct a career ladder for a cadre of elite civil servants. Career-based elite civil services, such as those in the Republic of Korea and Malaysia, are staffed via entry-level recruitment according to performance on an elite exam, with small proportions being nominated to serve from within the existing civil service (World Bank 2012c). If successfully implemented, this would endow the Myanmar government with a young, cohesive cohort of civil servants who could be induced to stay long-term by informal social bonds. While attractive, this option would not fulfill the present staffing needs of the Myanmar government, which likely needs to be supplemented at the outset with a broader civil service based on performance

\footnotetext{
${ }^{19}$ As of November 23, 2014.

20 "Salaries of skilled workers in Myanmar to rise up to 50\%," Eleven, October 22, 2012, http://elevenmyanmar.com/business/1038-salaries-of-skilled-workers-in-myanmar-to-rise-up-to-50.
} 
reports. These elite services act as teams within the broader bureaucracy and can be significant agents of change.

A complementary measure would be to offer delayed rewards: establishing attractive pensions and retirement benefits, such as subsidized insurance. This strategy may be advisable for two reasons. First, the deferment of benefits to late life means that the effect on current expenditures need not be as large as with wage increases (Becker and Stigler 1974). Second, these types of benefits would have minimal impact on inflation, as they would not entail large injections of cash into the local economy. Another option would be to reward performance. Implementing a two-tier salary structure, consisting of a base wage and a variable wage that would be based on performance, would be one way of addressing this issue. Finally, another option would be to enhance recruitment efforts aimed at those individuals who are discriminated against in the private labor market for reasons of disability, gender, or religion. These individuals can be recruited and retained at lower costs. This suggestion should not be taken as encouraging discrimination, but rather recognizing that it exists and can be exploited by the public sector. Moreover, a diversification of the civil service could enhance central government credibility among peripheral minority groups.

President Thein Sein designated 2013 the year for public sector reform, with the goal of streamlining the policy making process. The Ministries of National Planning and Finance were intended to emerge as policy coordinators. This process created interministerial committees, including the National Energy Management Committee and the Energy Management Committee, composed of representatives of the Ministries of Energy, Electric Power, Agriculture and Irrigation, Environmental Conservation and Forestry, Industry, Mines, and Science and Technology. While these bodies have a specific mandate to break down stovepipes in policy formation, they lack independent secretariats. Whatever issues or policy initiatives emerge out of the committee meetings are then reassigned to the independent ministries later. Providing these units with independent secretariats would be a useful step in enhancing policy coordination. The ADB is providing some support for the development of a 20 -year, integrated energy master plan, but similar infusions of resources - and help with cross-ministry planning and coordination - would be welcome (ADB 2013). At the national level, the Ministry of National Planning should be tasked with coordinating policy. Policy coordination between a coordinating ministry and a line ministry is difficult enough; divvying up the coordinating responsibilities between two ministries amplifies the associated problems. If planning and finance are so intimately linked that assigning the master planning role to one ministry would be unworkable, another model would be to merge the Ministries of National Planning and Finance. The Republic of Korea did just this in 2008, with the state rationale being "to put under one roof fiscal policy functions and inter-ministerial policy coordination" (Ministry of Strategy and Finance 2010).

Policy coordination between the central government and state and regional governments will be an increasingly important issue. The 2008 constitution established state and regional governments, ${ }^{21}$ each with the constitutional power to levy excise, land, and water taxes, as well as toll fees and royalties on marine fisheries. Moreover, state and regional governments will be responsible for implementing central government directives alongside central government ministries. Additional staffing demands will be significant. The state and regional governments will form their own cabinets, with ministers drawn from the elected state and regional Hluttaws and subject to final approval by the president. As at the national level, the minister for border and security affairs will be appointed by the commander-in-chief of the

\footnotetext{
${ }^{21}$ States and regions are equivalent. The term state applies to those administrative units encompassing regionally concentrated ethnic minorities (Chin, Kachin, Kayah, Kayin, Mon, Rakhine, and Shan), while the regions are composed of majority Burman areas (Ayeyarwady, Bago, Magway, Mandalay, Sagaing, Taninthyari, and Yangon). The capital, Naypyidaw, is administered as a union territory.
} 
defense services. However, these ministries will not have direct power over hiring and promotion in these bureaucracies, which will be conducted by the national line ministries. This practice blurs the lines of delegation, with bureaucrats potentially receiving conflicting directives and assignments from national and state- and regional-level ministers. Moreover, regional ministers will be fewer in number than line ministries, meaning that individual regional and state ministers will have to shoulder multiple portfolios with a single ministry's staff and resources (Nixon et al. 2013). These circumstances are ripe for an increase in corrupt practices, as blurred lines of delegation complicate oversight.

\section{Engaging Civil Society and the Peace Process}

\section{Civil Society}

Since 2011, the Myanmar government has enacted wide-ranging reforms that should support development of a more robust civil society, even if they fall short of guaranteeing true freedom of press and assembly. Press censorship has been eased by the abolition of the Press Scrutiny and Registration Division. Prior to its abolition in 2012, all newspaper articles were subject to its purview. The state's monopoly on daily print media has ended as well. As of April 1, 2013, four privately owned daily newspapers went into circulation, though private newspapers still require government-issued permits. ${ }^{22}$ These reforms have been noticed: In just two years (2012-2014), Myanmar moved from 169 to 145 on Reporters Without Borders' World Press Freedom Index, putting it ahead of regional comparators Malaysia and Viet Nam (Reporters Without Borders 2014).

The Law on Peaceful Assembly and Peaceful Procession, enacted July 5, 2012, allows the right to hold peaceful demonstrations and marches, though organizers must obtain permission five days in advance from the commander of the relevant Township Police Force. Applications are not to be denied unless they pose a threat to state security, the rule of law, or "public tranquility," though these terms are left without precise definition, and thus regional police commanders have wide latitude in determining what constitutes a threat (Ministry of Home Affairs 2012).

The Myanmar National Human Rights Commission was empaneled in 2011; it has repeatedly called for the president to grant amnesty to political prisoners and exiles. Over 6,000 such prisoners were released on October 11, 2011 (NHRC 2011), and hundreds of political dissidents have returned from abroad after the government removed over 2,000 individuals from a "blacklist" that prohibited entry into the country. Nevertheless, the NHRC has thus far not investigated claims of human rights abuses in conflict zones, where conditions are likely much worse.

A welcome sign has been an enhanced role for civil society in the policy formation and advising process. As discussed above, an independent think tank, the Myanmar Development Resource Institute was formed. It consists of three components: economics, law, and security and political affairs. This group has been tasked with acting as the secretariat in Myanmar's EITI application (see following section). As Myanmar's private sector develops, opportunities to leverage private expertise through public-private partnerships (PPPs) should be expanded as well (ADB 2008). While many PPPs take the form of large investment projects, cofinanced by private firms and governments, PPPs can also take the form of contracting with private sector firms to provide highly specialized services to the government. PPPs have been a widely used mechanism for developing infrastructure, particularly in the areas of telecommunications, power generation, water and sanitation, and transportation infrastructure. Given

\footnotetext{
${ }^{22}$ Sixteen separate newspapers were granted licenses by the Myanmar government. See "Private dailies re-emerge in Myanmar, face difficulties," Reuters, April 1, 2013.
} 
Myanmar's needs in all these areas PPPs may help channel private investment into the provision of public services.

Improvements in communications infrastructure will help spur both economic growth and civil society. As of 2012, only one out of 100 Myanmar people had internet access, and telephone lines were similarly scarce. Cellular subscriptions, however, are up over 800 percent since 2010 , with more than 5 million cellular subscribers nationwide (World Bank 2013a). The telecommunications sector was recently opened to foreign investment, which is expected to make cell phones less expensive and thus within reach of the broader population. As has been the experience in other countries, this is expected to have both economic and social-political effects by facilitating communication among private citizens.

While the long-term effects of a burgeoning civil society will likely be very positive, the opening of political space for private, nonstate actors is not always an unalloyed blessing. Independent civil societies can and will mobilize to protest reforms, particularly those that entail the withdrawal of perceived benefits. Moreover, not all civil society actors are necessarily benevolent, which implies that the government must play a larger role in punishing and deterring such violent actions, especially as they may have the potential to escalate.

\section{Peace Process}

Myanmar's past history of unrest has been a significant brake on economic development. While countryspecific estimates are not feasible, Valerie Cerra and Sweta Saxena (2008) estimate the output loss from a civil war in low-income countries to be significant (on average, 6 percent), and higher for those with comparatively weak checks on executive power. Conflict in Myanmar has complicated efforts to combat narcotics production, illegal mining, and logging, the latter of which constitutes a significant loss of both export and government revenue. More generally, concerns about political instability drive down foreign direct investment, especially in nonresource sectors like light manufacturing.

On September 10, 2013, Minister of the President's Office Aung Min met with the United Nationalities Federal Council (UNFC) members to discuss plans for a national ceasefire agreement. If successful, it could pave the way to a more comprehensive peace agreement. However, just 10 days later, the UNFC announced that it would not accept the government's offer, in part due to continued fighting in Kachin and Shan states. Tensions rose further in November 2014 following the shelling of a Kachin training facility, which resulted in the deaths of 23 cadets of the Kachin Independence Army (the militant wing of the Kachin Independence Organization); the action was condemned by the UNFC. Despite dayto-day uncertainty, these most recent ceasefires differ significantly from those of the past. The most recent ceasefires have been (a) written, rather than verbal, (b) openly reported by media outlets, meaning that public awareness of the ceasefires has been significantly enhanced, (c) involve not just field military commanders, but delegates of the highest levels of the civilian government, and (d) explicitly tackle the issue of armed group involvement in illicit activities (Yawnghwe and Maung Than 2011).

While these are positive developments, a ceasefire should not be viewed as marking the cessation of hostilities. Conflict could resume if the underlying issues that generated the conflicts are not addressed. The 2010 constitution began the process of transitioning more governance roles to regional governments, thereby granting minority groups greater policy autonomy. However, the stability of these ethno-federal and/or power-sharing arrangements is not guaranteed. Arend Lijphart (1977), Alfred Stepan (1999), and Ted Robert Gurr (2000) all argue the merits of decentralization, through either federalism or some powersharing arrangement, as a solution to rule in ethnically divided societies. Power-sharing arrangements are those that build in representation for various identity groups in order to insure that their interests are represented in postconflict governance institutions. Caroline Hartzell and Matthew Hoddie (2003) find 
that power-sharing institutions across a wide range of areas-economic, military, political, and territorial autonomy - are associated with a decreased likelihood of return to conflict, though their findings are based on small samples.

There are dissenting views as well. Dawn Brancati (2006) finds that ethno-federalism reinforces ethnic and regional identities and party cleavages, producing legislation that favors certain groups over others, and mobilizing groups to engage in ethnic conflict and secessionism. Thomas Christin and Simon Hug (2012) note that this tendency is strongest when ethnic groups are highly geographically concentrated - a condition that definitely obtains in Myanmar. Alternately, Kristin Bakke and Erik Wibbels (2006) note that the stability of ethno-federal arrangements is conditional on a society's level of economic development and ethnic composition. Alternately, Philip Roeder and Donald Rothchild (2005) argue in favor of power-dividing, rather than power-sharing arrangements. Power-dividing institutions stress the importance of multiple, overlapping majorities and checks and balances as well as universal protection of civil liberties and ethnic and religious identities. Roeder and Rothchild find that powerdividing, rather than power-sharing, institutions are associated with more robust peace following civil wars.

Whatever the resolution of existing conflicts, further institutional reforms are likely necessary to encourage the development of broad-based political parties that have support across ethnic and regional lines. The current electoral system, in which legislative candidates compete for a single seat (single member district plurality) within relatively ethnically and religiously homogeneous districts, does not encourage politicians to seek support outside of their own group. These systems tend to disproportionately reward large national parties and smaller parties with highly geographically concentrated bases of support, such as the various regional parties, while underrepresenting smaller, less geographically concentrated parties.

Electoral systems research comes up with three classes of solutions: closed-list proportional representation; rules that require parties to run candidates across the country, rather than just in ethnic homelands, as in Indonesia ${ }^{23}$; and preferential voting systems. In preferential voting systems, voters rank their preferences over candidates within their district (Reilly 2002). The idea is to encourage parties not just to campaign for first-place votes but to court second-place votes as well, pooling votes across ethnic lines and thus decreasing ethnic identity as a salient driver of political affiliations. Alternative vote is a single member district system that requires an absolute majority, rather than plurality; if an absolute majority is not gained in the first round, the candidate with the lowest number of first-place votes is eliminated, and their votes are distributed to the remaining candidates. Single transferable vote is a proportional representation system with multimember districts, with a "quota" of votes required to elect a single candidate, and a subsequently similar redistribution of remaining first-place votes. Either of these reforms would help to reduce the salience of ethnic identity in partisan politics.

\section{External Policy Anchors and the Extractive Industries Transparency Initiative (EITI)}

Myanmar is reforming its policies and practices on governance. External anchors can be used to promote internal reforms, reinforce credibility, and lock in commitments. In particular, Myanmar's transformation is occurring in the context of a massive resource boom. EITI and other international anticorruption efforts can be used to deepen and strengthen Myanmar's ongoing efforts in this area.

\section{Resource Development Context}

${ }^{23}$ Joel Selway, “In Myanmar, An Election Doomed to Fail,” New York Times, March 30, 2012. 
Myanmar has incredibly rich and diverse mineral resources, ranging from precious stones to oil and natural gas. The country has an estimated 283 billion to 334 billion cubic meters of natural gas, with much higher reserve potential, along with 50 million barrels of crude oil reserves (US Energy Information Administration 2013, British Petroleum 2013). The country has 90 percent of the world's jade reserves. The official jade market is large and in reality potentially perhaps 40 percent larger due to the illicit nature of much of the trade and the location of many significant deposits in areas of political conflict, particularly Kachin and Shan states. A revision of the 1994 Mining Law is being contemplated. A strengthened legal framework, streamlined approvals process, and a removal of export bans on certain minerals could induce billions of dollars of FDI inflows and transform the sector.

In addition to minerals, Myanmar exports considerable timber (perhaps more than 2.5 million cubic meters), though assessing the true volume of timber exports, as in the case of semi-precious stones, is impeded by the problem of illegal exports (Woods 2013).

Energy and minerals account for perhaps half of exports, and foreign direct investment has been overwhelmingly targeted at the mineral and natural gas sectors. Sixty-one companies, including Total, Eni, and other large multinationals that are EITI stakeholders, have registered to bid on both onshore and 30 offshore blocks in 2013; 20 more offshore oil and gas blocks were auctioned to companies including Royal Dutch Shell, Total, and Statoil, with a further nine blocks to be auctioned in 2015. Pipelines to carry the oil and gas to end-users traverse the country, including through areas largely inhabited by ethnic minorities, and protests have at times disrupted the operation of oil and gas pipelines.

An open issue is whether economic and political institutions are capable of successfully managing the sudden influx of wealth this mineral boom will generate, or whether the wealth will complicate macroeconomic management, inhibiting development of nonenergy sectors and complicating the country's political reforms.

Countries whose wealth is heavily derived from the exploitation natural resources tend to be poorer and grow more slowly than those whose wealth is based on the accumulation of human and physical capital. However, the empirical literature on the resource curse - the tendency of resourcedependent economies to grow more slowly for purely economic reasons, such as resource pulls and crowding out, Dutch disease, price volatility, etc.- has reached consensus that these economic phenomena cause only slightly negative effects. The potentially most deleterious effects of natural resource wealth on economic development may rather operate indirectly, through institutions and conflict.

Dependence on high-value, mined commodities has negative effects for bureaucratic and state capacity and political violence - all of which exert direct or indirect effects on economic growth. It is perhaps no accident that the two countries with which Myanmar tied for last place in the open budget index were Qatar and Equatorial Guinea, two oil exporters. However, the negative effects for bureaucratic capacity and political violence - the factors with the clearest implications for economic growth-are found to be largely contingent on the quality of preexisting institutions and, in the case of conflict, certain attributes of the resources themselves.

Whether natural resource wealth leads to violence is largely a function of both attributes of the resource itself and the technology of its extraction, and the preexisting political, economic and social environment. Commodities with high value-to-weight ratios, such as gemstones, oil, cocaine, and opium, are ideal contestable, or "lootable," goods, and indeed the gem trade has fueled some of Myanmar's peripheral insurgencies for decades.

With respect to hydrocarbons, location is key. The relevant distinction is onshore versus offshore production. Onshore oil production increases the probability of conflict onset by 50 percent relative to the baseline risk, in contrast to offshore production, which has no effect. This disparity in impact across the 
two settings is due to the differential opportunities onshore versus offshore production create for rent seeking by violent actors. Transporting onshore hydrocarbons to terminals for export generally requires large, aboveground networks of pipelines. This onshore infrastructure creates a network of targetsincluding pipelines and the workers who service them - only a few of which can truly be hardened against attack. Deep-pocketed energy companies make attractive targets for insurgents, who may have limited capacity to hold and defend such installations but significant capacity to extort. Myanmar's own experience with its pipeline through Shan state - which has been sabotaged by insurgents in the pastshows this in action. In contrast, offshore platforms are comparatively easy to defend, since most insurgent groups do not have naval capacity and have limited capacity to extract rents from offshore production. As Myanmar's production transitions to more offshore gas fields, its gas infrastructure will be less prone to sabotage.

Many seemingly resource-related conflicts have occurred in societies that would be among the most-likely candidates for conflict outbreak, even absent the role of contestable resources: Countries like Colombia, Indonesia, and Myanmar are at elevated risk of experiencing conflict because of past histories of violence, comparatively low levels of economic development, and horizontal inequalities. For this reason, political reforms aimed at redressing horizontal inequalities - such as those between the ethnic majority and minorities - are vital.

\section{The Extractive Industries Transparency Initiative (EITI)}

Policy concerns regarding the potentially negative institutional aspects of the resource curse fall into two basic categories. The first revolve around fiscal issues. Proposed solutions typically involve the adoption of fiscal policy rules (including the possibility of dedicating or earmarking expenditures for particular programs with the expectation that they will generate a broad political constituency for transparency and accountability), the creation of natural resource or sovereign wealth funds, and/or direct distribution of resource rents via cash transfers/dividends to the public, or what has been called "oil to cash." Each of these proposals has merits and drawbacks, and some judicious mixture of all three (a natural resource or sovereign wealth fund, earmarks for particular programs, and dividends payments) may be ideal. However, in this context we focus on institutional concerns that are much more foundational to economic development than any specific policy intervention.

Over the past decade, a number of international good governance initiatives, including the Kimberley Process Certification Scheme (KPCS) and associated Diamond Development Initiative, the Extractive Industries Transparency Initiative (EITI), and the Conflict Minerals Trade initiative, have emerged to address the resource management challenges described in the previous section. ${ }^{24}$ In July 2014 , Myanmar was accepted as a candidate country to the EITI, the focus of this section. ${ }^{25}$ It is also pursuing a pilot project to push down EITI to the state level.

EITI works off of two components: disclosure, which is supposed to generate the information needed to reduce corruption, and the establishment of country-level multistakeholder bodies, which in principle absorb and propagate this information to enforce accountability.

The first component aims to build double entry accounts that can be checked for consistency. Governments must require extractive firms operating within their territory to disclose payments to

\footnotetext{
24 This section draws on Hendrix and Noland (2014). In addition to the initiatives mentioned above, the European Union, United States, and Australia all maintain their own regulations on the importation of timber from Myanmar, which have created a trade regime somewhat similar to the conflict minerals regulatory regime.

${ }^{25}$ The United States is also in the process of applying to EITI and has entered into a partnership with Myanmar to provide political and technical assistance to implement best practices in the oil, gas, and mining sectors.
} 
governments to explore or extract energy or minerals, and governments must record revenues that they receive from extraction. A third-party independent administrator reconciles these figures. A current source of contention is whether those payments are aggregated or reported on a company-by-company basis, as is now required by laws in the United States and European Union. Roughly half of EITI member countries publish only aggregate amounts; the other half publish their results by company (Moran 2013). ${ }^{26}$ Myanmar can choose to make such reporting mandatory.

The second component is the establishment of a formal multistakeholder group that evaluates the information provided by the firms, the government, and the third-party administrator. Finally, an outside body validates the reports in conjunction with the stakeholder group. The external validation is supposed to close a loop between the government and the governed.

There are two tiers of countries in EITI: candidate countries, which have signed up to implement the EITI protocol, and compliant countries, which have fully and successfully implemented EITI. As of November 2014, there are 31 compliant countries, 17 candidate countries, 8 stakeholder nongovernmental organizations (NGOs), more than 80 supporting companies, more than 80 supporting institutional investors, and 21 stakeholder organizations, including the Asian Development Bank. Petrobras (Brazil) is an EITI supporter, but other large non-Western oil companies such as China National Petroleum Company, Lukoil (Russian Federation), and Petronas (Malaysia) are not. ${ }^{27}$

While EITI was originally oriented toward the oil sector, several signatories produced other minerals and were not primarily oil producers. EITI is being expanded to include fisheries and forestry in some countries. There is no reason, for example, that Myanmar cannot also apply EITI to the production of timber, and not just oil, gas, and minerals. ${ }^{28}$

The effectiveness of EITI is in significant part a function of the degree of buy-in by host governments. The pact is voluntary. A government committed to behaving corruptly may simply not participate. There is no mechanism for directly sanctioning noncompliance, though there may be reputational or signaling costs. ${ }^{29}$ EITI focuses on a single point in the production chain (the transfer of money from the firm to the government) and ignores critical upstream stages (contracting and procurement) and downstream activities (expenditure).

The stakeholder body is also potentially a point of weakness depending on the preexisting strength of civil society and on the attitude of the government. EITI creates a platform for communication between the government, the companies, and civil society and establishes a set of internationally accepted norms and procedures. But in some countries, particularly those that have recently transitioned from more autocratic forms of rule, the press and NGOs remain weak, making effective civil society participation difficult. And in some other countries, the government literally appoints the stakeholder representatives, allowing it to pack the body with cronies who may have little interest in rocking the boat. Similarly, EITI may spur national legislation to strengthen regulation of the extractive sector.

\footnotetext{
${ }^{26}$ See Darby (2009) on the rationale for company-by-company disclosure.

${ }^{27}$ See EITI website, http://eiti.org/supporters/companies (accessed on November 20, 2014).

${ }^{28}$ Myanmar has a legal regime for timber exports requiring certification by MTE and exportation via the port of Yangon and banned the export of raw logs on April 1, 2014. Neighboring importing countries, the People's Republic of China (PRC) and Thailand, also have laws prohibiting the import of illegal Myanmar timber. However, the enforcement of these laws is ineffective, and improper certification of illegally logged timber has created problems exporting to the European Union and United States (Woods 2013).The Environmental Investigation Agency, a British NGO, estimates that between 2000 and 2013 almost half of the timber logged in Myanmar was cut illegally and that nearly three-quarters of exports, worth $\$ 5.7$ billion, were smuggled illegally out of the country (Environmental Investigation Agency 2014).

${ }^{29}$ For example, Rex Tillerson, Exxon Mobil CEO, subsequently argued that host-country adherence to EITI signals a commitment to strengthen the business-enabling environment and for example encouraged Equatorial Guinea to join (Aaronson 2011). (The country began the implementation process but was delisted in 2010.)
} 
One barrier to implementation has been a simple lack of accounting expertise. The NGOs Publish What You Pay and Transparency International train budget activists, and the Revenue Watch Institute has developed educational materials for journalists and civil society groups. The World Bank has launched an "EITI++" program, which assists host governments from the initial bid tendering stage through expenditure management. The ability of these initiatives for fostering civil society, as distinct from providing technical assistance to functioning civil society groups, is unclear. Ultimately EITI is only as effective as there are mechanisms, including a free press, which allows citizens to exert accountability over their government. In this regard, Myanmar's recent moves toward greater budget transparency and enhanced civil and political freedoms, including critically, press freedoms, make it more likely that EITI can function successfully as intended in Myanmar.

Producers from nonsignatory countries are steadily becoming entangled in the regime. One prong is EITI itself: As more countries begin implementing EITI and validation standards tighten, more and more companies will be subject to host government pressure to participate.

The other prong consists of laws and regulations in the US, EU and other jurisdictions. Foreign firms listing on US stock exchanges must observe US law, which embodies increasing rigor with respect to transparency and disclosure. ${ }^{30}$ Companies are expected to begin reporting in 2015-16. ${ }^{31}$

In the case of the European Union, the European Commission proposed one set of rules in June 2012, but the European Parliament passed stricter regulations in September 2012. After consultations, in April 2013 the European Parliament overwhelmingly passed legislation going further than the DoddFrank Act, requiring resource companies to publish total payments, taxes on profits or production, royalties dividends, bonuses, related fees, and payments for infrastructure improvements for any project generating more than $€ 100,000$ in revenues. Together the US and EU regulations would cover about 70 percent of value in global extractive industries. As of November 2014, an Extractive Sector Transparency Measures Act, supported by Canadian Prime Minister Stephen Harper, is before the Canadian Parliament.

Bribing public officials is broadly illegal throughout the world due to the 1977 Foreign Corrupt Practices Act (FCPA), which American authorities have applied extraterritorially, and the counterpart 1997 OECD Convention on Combating Bribery of Foreign Public Officials in International Business Transactions, ${ }^{32}$ and similar national and regional laws passed since (Danielsen and Kennedy 2011). For example, Britain's 2010 Bribery Act goes farther than FCPA, making it illegal to receive a bribe from or bribe private officials, but also contains an adequate preventative measures provision that would appear to make it marginally easier for a defendant to insulate itself legally from the profit-maximizing malfeasance of its employees and agents (Rose-Ackerman 2010, Danielsen and Kennedy 2011).

\footnotetext{
${ }^{30}$ According to Theodore Moran (2012), in 2012 the Hong Kong, China stock exchange adopted similar rules.

${ }^{31}$ The American Petroleum Institute filed a lawsuit to block the Securities and Exchange Commission (SEC) implementation of Section 1504 of the Dodd-Frank Act. The industry position is that subjecting US and EU firms to these requirements would create an unlevel playing field with respect to their non-Western competitors, and that the disclosure requirement could conflict with confidentiality agreements required by some host governments, including Angola, Cameroon, the PRC, and Qatar, effectively requiring firms to break either the law of the United States and/or the European Union or the law of their hosts. US and EU laws assert their primacy in this situation.

In July 2013, the US District Court for the District of Columbia ruled in favor of the oil companies, accepting the industry's argument that the payment reports should go to the SEC privately and not be made public. The court sent the regulations back to the SEC for revision. These revisions, and what if any impact the court ruling might have for developments in the European Union, Canada, and elsewhere are unclear at this writing. Large US firms such as Exxon-Mobil, Chevron, and CononoPhilips would still be covered under the stricter EU laws since they list on European stock exchanges.

32 This convention has been ratified by all members of the OECD as well as six nonmember countries-Argentina, Brazil, Bulgaria, Colombia, Russian Federation, and South Africa. Enforcement is via national law, with a peer-review mechanism to encourage diligence.
} 
The oil and gas sector appears to be especially prone to bribery (Weismann 2008; Sanyal 2012, table 1). There is some statistical evidence that US anticorruption enforcement officials may act altruistically, imposing proportionately greater fines for violations committed in low-income countries (Choi and Davis 2012). Whether employees of SEEs and sovereign wealth funds count as "foreign officials" under FCPA is an unresolved issue that may take on greater salience in the future (Rose 2012). So, for example, if the management of Myanmar SEEs is defined as "foreign officials" for the purposes of US law, then bribery involving management of Myanmar SEEs by firms falling under the jurisdiction of the FCPA would be subject to prosecution in the United States. ${ }^{33}$ The FCPA is a potentially powerful tool for checking corruption within Myanmar, insofar as Myanmar authorities could appeal to counterparts in the US, EU, and other jurisdictions with strong antibribery statutes for assistance in investigation and prosecutions. For example, the government of Ghana successfully enlisted the participation of the US Department of Justice in an investigation into corruption in that country's oil industry that involved a firm located in the United States. Similarly, the government of Guinea has enlisted the cooperation of Swiss and American authorities to pursue allegations of corruption by foreign investors under the previous authoritarian regime in that country's oil and mining industries.

Ultimately the effectiveness of EITI and other good governance initiatives to generate better development outcomes in the long run is conditioned on a number of political and institutional factors, such as the existence of a free press and a robust civil society. Myanmar is making progress in these areas, though it is not plausibly under the control of the agencies implementing EITI and related initiatives. A holistic approach is needed to address these multifaceted concerns.

\section{Conclusion}

The government of Myanmar faces important decisions that will determine the future trajectory of governance reform and condition long-run growth and poverty reduction. Since 2010, the pace of reform has been nothing short of stunning, yet significant challenges remain. While the agenda for continued reform is extensive, we identify the following items as crucial for enhancing government effectiveness and locking in recent gains in this area:

1. Increasing bureaucratic salaries and diversifying the candidate pool by targeting underrepresented groups and those likely to face some discrimination in the private labor market.

2. Developing an elite cadre of senior civil servants as a desirable career path.

3. Streamlining the number of line ministries, cutting their number roughly in half, while shifting staffing to interministerial coordinating secretariats. In particular, the government should consider merging the Ministries of National Planning and Finance to unite strategic planning and budgeting under one ministry.

4. Achieving a comprehensive ceasefire with various armed groups.

5. Reforming electoral law to encourage development of more national parties, either by requiring parties to run candidates in all constituencies or by introducing some form of preference voting.

\footnotetext{
${ }^{33}$ The trend is clearly toward ratcheting up disclosure requirements for a broad swath of producers. For example, all four of the PRC's major oil companies have foreign operations and all are listed on the New York Stock Exchange (therefore subject to FCPA). Many of the PRC's major extractive firms are in joint ventures with Western multinationals such as Total, BP, and BHP Billiton, and thus are included in these operations by extension, though as Moran (2012) observes, there may be significant gaps with respect to coverage of non-Western producers. Moran $(2012,2013)$ notes that a number of major Russian, Chinese, and Indian oil and mining companies do not list in New York or Hong Kong, China and thus would not be subject to EITI via those channels. The regulations also do not apply to foreign issuers of American depositary receipts, such as Lukoil and Gazprom.
} 
6. Increasing involvement of the private sector (private industry, think tanks, and independent educational institutions) in the policy formation process.

7. Conducting a comprehensive land survey — security conditions permitting — in order to establish a current cadaster map of the country's territory and promote transparency in land use and tenure. The Ministry of Finance and Revenue should conduct this survey.

8. Using EITI as a means to lever Myanmar's indigenous good governance efforts in the extractive sector, and more broadly, exploiting opportunities to anchor broader policy reforms, including anticorruption efforts, to international best practices. Specifically, in implementing EITI Myanmar can

- require company-by-company disclosure,

- extend EITI to oil, gas, minerals, and timber,

- look favorably on bids by EITI stakeholder firms committed to transparency, and

- participate in EITI+ and EITI++ extending the transparency initiative upstream to contracting and procurement and downstream to expenditure.

Likewise, a similar set of arguments holds for foreign anticorruption statutes such as the US FCPA more broadly. Specifically, the government of Myanmar should look favorably on bids by firms based in jurisdictions with strong antibribery laws and enforcement, thereby "piggy-backing" on the more rigorous standards of foreign partners; if firms that fall under the jurisdiction of those governments (whether they be headquartered in that country or not) while in Myanmar violate those countries' anticorruption laws, then the government of Myanmar can appeal to those foreign governments for support in prosecuting corrupt activity. When evaluating potential foreign participants in resource extraction the government of Myanmar should take into account whether those firms are subject to the laws of the United States, the European Union, or other jurisdictions with strong antibribery laws and histories of extraterritorial legal cooperation, and give preference to those firms (regardless of nationality) whose behavior in Myanmar will be constrained by anticorruption statutes elsewhere. In short, Myanmar should use international initiatives such as EITI and FCPA to leverage its reform efforts while building its indigenous institutional capacity.

\section{References}

Aaronson, Susan Ariel. 2011. Limited Partnership: Business, government, civil society, and the public in the Extractive Industries Transparency Initiative (EITI). Public Administration and Development 31, no. 1 .

ADB (Asian Development Bank). 2008. Public-Private Partnership Handbook. Manila.

ADB (Asian Development Bank). 2013. Institutional Strengthening of National Energy Management Committee in Energy Policy and Planning. ADB Project Datasheet, September 13. Manila. Available at www.adb.org/projects/46389-001/main (accessed on September 28, 2013).

Bakke, Kristin, and Erik Wibbels. 2006. Diversity, Disparity, and Civil Conflict in Federal States. World Politics 59, no. 1: 1-50.

Becker, Gary S., and George J. Stigler. 1974. Law Enforcement, Malfeasance, and Compensation of Enforcers. Journal of Legal Studies 3, no. 1: 1-18.

Besley, Timothy, and John McLaren. 1993. Taxes and Bribery: The Role of Wage Incentives. Economic Journal 103, no. 416: 119-41. 
Binns, Bernard O., and Peter F. Dale. 1995. Cadastral Surveys and Records of Rights in Land. FAO Land Tenure Studies \#1, revised edition. Rome: Food and Agriculture Organization.

Brancati, Dawn. 2006. Decentralization: Fueling the Fire or Dampening the Flames of Ethnic Conflict and Succession? International Organization 60, no. 3: 651-85.

British Petroleum. 2013. Statistical Review of World Energy. London.

Cerra, Valerie, and Sweta Chaman Saxena. 2008. Growth dynamics: The myth of economic recovery. American Economic Review 98, no. 1: 439-57.

Choi, Stephen J., and Kevin E. Davis. 2012. Foreign Affairs and Enforcement of the Foreign Corrupt Practices Act. Public Law and Legal Theory Research Paper Series Working Series no. 12-35. New York: New York University School of Law.

Christin, Thomas, and Simon Hug. 2012. Federalism, the Geographic Location of Groups, and Conflict. Conflict Management and Peace Science 29, no. 1: 93-122.

CIA (Central Intelligence Agency). 2014. Chiefs of State and Cabinet Members of Foreign Governments: A Directory. Washington.

Clapp, Priscilla, and Suzanne DiMaggio. 2013. Sustaining Myanmar's Transition: Ten Critical Challenges. Washington: Asia Society.

Danielsen, Dan, and David Kennedy. 2011. Busting bribery: Sustaining the global momentum of the Foreign Corrupt Practices Act. New York: Open Society Foundations.

Darby, Sefton. 2009. The Case for Company-by-Company Reporting of Data in the Extractive Industries Transparency Initiative. Available at http://caspianrevenuewatch.org/images/RWI_EITI_AggDisaggReporting_Darby.pdf (accessed July 24, 2013).

Environmental Investigation Agency. 2014. Data Corruption: Exposing the true scale of logging in Myanmar. London. Available at www.burmalibrary.org/docs17/EIA-Data-Corruption-en.pdf (accessed November 30, 2014).

Freedom House. 2014. Country ratings and status: Freedom in the World 1973-2014. Available at www.freedomhouse.org/report-types/freedom-world (accessed November 20, 2014).

Givens, David. 2013. Defining governance matters: A factor analytic assessment of governance institutions. Journal of Comparative Economics 41: 1026-53.

Gurr, Ted Robert. 2000. Ethnic Warfare on the Wane. Foreign Affairs 79, no. 3: 52-65.

Hartzell, Caroline, and Matthew Hoddie. 2003. Institutionalizing Peace: Power Sharing and Post-Civil War Conflict Management. American Journal of Political Science 47, no. 2: 318-32.

Hendrix, Cullen S., and Marcus Noland. 2014. Confronting the Curse: The Economics and Geopolitics of Natural Resource Governance. Washington: Peterson Institute for International Economics.

Heritage Foundation. 2014. Index of Economic Freedom 1995-2014. Available at www.heritage.org/ index/explore?view=by-region-country-year (accessed on November 20, 2014).

IMF (International Monetary Fund). 2010. 2009 Article IV Consultation with Myanmar. Washington.

IMF (International Monetary Fund). 2012. World Economic Outlook Database. Washington. Available at www.imf.org/external/pubs/ft/weo/2012/01/weodata/index.aspx (accessed on September 20, 2013).

IMF (International Monetary Fund). 2013. Myanmar: 2013 Article IV Consultation and First Review under the Staff-Monitored Program. IMF Country Report No. 13/250. Available at www.imf.org/external/ pubs/ft/scr/2013/cr13250.pdf (accessed on September 27, 2013).

IMF (International Monetary Fund). 2014a. Myanmar: 2014 Article IV Consultation. IMF Country Report No. 14/307. Washington. 
IMF (International Monetary Fund). 2014b. World Economic Outlook Database (April). Available at www.imf.org/external/pubs/ft/weo/2014/01/weodata/download.aspx (accessed November 23, 2014).

International Budget Partnership. 2012. Open Budget Survey 2012. Washington.

International Budget Partnership. 2013. The Open Budget Index 2006-2012. Available at http://survey. internationalbudget.org/\#download (accessed on September 22, 2013).

Kaufmann, Daniel, Aart Kraay, and Massimo Mastruzzi. 2010. Worldwide Governance Indicators: Methodology and Analytical Issues. World Bank Policy Research Working Paper 5430. Washington: World Bank.

Klimek, Peter, Rudolf Hanel, and Stefan Thurner. 2009. To How Many Politicians Should Government Be Left? Physica A: Statistical Mechanics and its Applications 388, no. 18: 3939-47.

Kubo, Koji. 2012. Myanmar's Two Decades of Halfway Transition to a Market Economy: A Negative Legacy for the New Government. In Economic Reforms in Myanmar: Pathways and Prospects, ed. Hank Lim and Yasuhiro Yamada. BRC Research Report No.10: Bangkok, Thailand: Bangkok Research Center, IDE-JETRO.

Lijphart, Arend. 1977. Democracy in Plural Societies: A Comparative Exploration. New Haven: Yale University Press.

McKinsey Global Institute. 2013. Myanmar's Moment: Unique Opportunities, Major Challenges (June). Available at www.mckinsey.com/insights/asia-pacific/myanmars_moment (accessed on February 19, 2015).

Mieno, Fumiharu. 2013. Toward Myanmar's New Stage of Development: Transition from Military Rule to the Market. Asian Economic Policy Review 8, no. 1: 94-117.

Min, Aung, and Kudo, K. 2012. New Government's Initiatives for Industrial Development In Myanmar. In Economic Reforms in Myanmar: Pathways and Prospects, ed. Hank Lim and Yasuhiro Yamada. BRC Research Report No.10: Bangkok, Thailand: Bangkok Research Center, IDEJETRO.

Ministry of Home Affairs. 2012. Regulations relating to the Right to Peaceful Assembly and Peaceful Procession. Translation available at www.burmalibrary.org/docs15/2012-Peacefulprocession_regulations-en.pdf (accessed on September 27, 2013).

Ministry of Strategy and Finance. 2010. Ministry of Strategy and Finance (MOSF): History. Available at www.asia21.org/node/44 (accessed on November 19, 2013).

Moran, Theodore H. 2012. An Assessment of the Requirement that Oil, Gas and Mining Companies Registered with the U.S. Security and Exchange Commission Publish How Much They Pay to Governments Where They Operate. Unpublished paper. Available at www.cgdev.org/sites/default/files/Draft\%20CGD\%20Policy\%20Paper\%20-\%20EITI\%20\%20Moran_.pdf (accessed on July 24, 2013).

Moran, Theodore H. 2013. Reform EITI to Require Compliant Countries to Publish Disaggregated Company-by-Company Revenue Payments. Proposal for the Extractive Industries Transparency Initiative Strategic Review 2013. Washington: Center for Global Development.

Nehru, Vikram. 2013. Myanmar's Economic Policy Priorities. Carnegie Papers. Washington: Carnegie Endowment for International Peace.

NHRC (National Human Rights Commission). 2011. Myanmar National Human Rights Commission sends open letter to President, November 12. Available at www.burmalibrary.org/docs14/NHRCprisoners-NLM2011-11-13.pdf (accessed on September 18, 2013). 
Nixon, Hamish, Cindy Joelene, Kyi Pyar Chit Saw, Thet Aung Lynn, and Matthew Arnold. 2013. State and Region Governments in Myanmar. Asia Foundation/Myanmar Development Resources Institute.

OECD (Organization for Economic Cooperation and Development). 2013. Multi-dimensional Review of Myanmar, volume 1: Initial Assessment. OECD Development Pathways. Paris: OECD Publishing.

Pun, Serge. 2012. Remarks at CSIS Myanmar Conference, Washington, September 25.

Rahman, A.K.M. 1986. Legal and Administrative Measures Against Bureaucratic Corruption in Asia. In Bureaucratic Corruption in Asia: Causes, Consequences, and Controls, ed. Ledivina Carino. Quezon City: NMC Press, 109-162.

Reilly, Benjamin. 2002. Electoral Systems for Divided Societies. Journal of Democracy 13, no. 2: 15670.

Reporters Without Borders. 2014. World Press Freedom Index 2014. Paris: RSF.

Roeder, Philip G., and Donald S. Rothchild, eds. 2005. Sustainable Peace: Power and Democracy After Civil Wars. Ithaca: Cornell University Press

Rose-Ackerman, Susan. 2010. The Law and Economics of Bribery. John M. Olin Center for Studies in Law, Economics, and Public Policy Research Paper no. 408. New Haven, CT: Yale Law School.

Rose, Paul. 2012. State Capitalism and the Foreign Corrupt Practices Act. Working Paper Series no. 176. Columbus, OH: The Ohio State University Moritz College of Law.

Sanyal, Rajib. 2012. Patterns in International Bribery: Violations of the Foreign Corrupt Practices Act. Thunderbird International Business Review 54, no. 3: 299-309.

Steinberg, David I. 2013a. Burma/Myanmar: What Everyone Needs to Know, second edition. Oxford University Press.

Steinberg, David I. 2013b. Transforming "Outposts of Tyranny"? Lessons and Cautions: Myanmar's Liberalization and North Korea. Working Paper. Seoul: Asian Institute for Policy Studies.

Stepan, Alfred. 1999. Federalism and Democracy: Beyond the US Model. Journal of Democracy 10, no. 4: 19-34.

Themner, Lotta, and Peter Wallensteen. 2013. Armed Conflicts, 1946-2012. Journal of Peace Research 50, no. 4: 509-21.

Transparency International. 2013. Corruption Perceptions Index 2013. Available at www.transparency.org/cpi2013/results (accessed on November 20, 2014).

Turnell, Sean. 2011. Fundamentals of Myanmar's Macroeconomy. Asian Economic Policy Review 6, no. 1: 136-53.

Turnell, Sean. 2014. Myanmar (partially) opens the door to foreign banks. East Asia Forum, October 13. Available at www.eastasiaforum (accessed November 21, 2014).

US Energy Information Administration. 2013. Burma (Myanmar). Country Analysis Note. Available at www.eia.gov/countries/country-data.cfm?fips=BM.

Van Rijckeghem, Caroline, and Beatrice Weder. 2001. Bureaucratic Corruption and the Rate of Temptation: Do Wages in the Civil Service Affect Corruption, and by How Much? Journal of Development Economics 65, no. 2: 307-31.

Vriens and Partners. 2013a. The New Myanmar. Issue 21, July 12.

Vriens and Partners. 2013b. The New Myanmar. Issue 24, August 23. Electronically published report. Vriens and Partners. 2013c. The New Myanmar. Issue 27, October 4. Electronically published report. Vriens and Partners. 2014. The New Myanmar. Issue 38, March 21. Electronically published report. Weismann, Miriam F. 2008. The Foreign Corrupt Practices Act: The Failure of the Self-Regulatory Model of Corporate Governance in the Global Business Environment. Journal of Business Ethics 88: 615-61. 
Woods, Kevin. 2013. Timber Trade Flows and Actors in Myanmar (November). Washington: Forest Trends Association.

World Bank. 2012a. 2012 Logistics Performance Index. Washington. Available at http://lpisurvey.worldbank.org/ (accessed on September 22, 2013).

World Bank. 2012c. Senior Public Service: High Performing Managers of Government. Washington. Available at http://www1.worldbank.org/publicsector/civilservice/epublishdocs/SPS\%20note\%201216.pdf (accessed on December 5, 2013).

World Bank. 2013a. World Development Indicators. Washington. Available at http://data.worldbank.org/data-catalog/world-development-indicators (accessed on September 25, 2013).

World Bank. 2013b. Worldwide Governance Indicators 2012. Washington. Available at http://info.worldbank.org/governance/wgi/index.aspx\#reports (accessed on September 22, 2013).

World Bank. 2014a. Doing Business 2015: Going Beyond Efficiency. Washington. Available at www.doingbusiness.org/reports/global-reports/doing-business-2015 > Accessed 20 November2014.

World Bank. 2014b. Worldwide Governance Indicators 2013. Washington. Available at http://info.worldbank.org/governance/wgi/index.aspx\#reports (accessed on February 10, 2015).

WEF (World Economic Forum). 2014. The Global Competitiveness Report 2014-2015. Available at http://reports.weforum.org/global-competitiveness-report-2014-2015/downloads/ (accessed on November 20, 2014).

Yawnghwe, Samara, and Tin Maung Maung Than. 2011. Ceasefires Sans Peace Process in Myanmar: the Shan State Army, 1989-2011. Asia Security Initiative Policy Series Working Paper no. 26.

Singapore: Center for Non-Traditional Security Studies. 


\section{Figure 1 The most problematic factors for doing business in Myanmar}

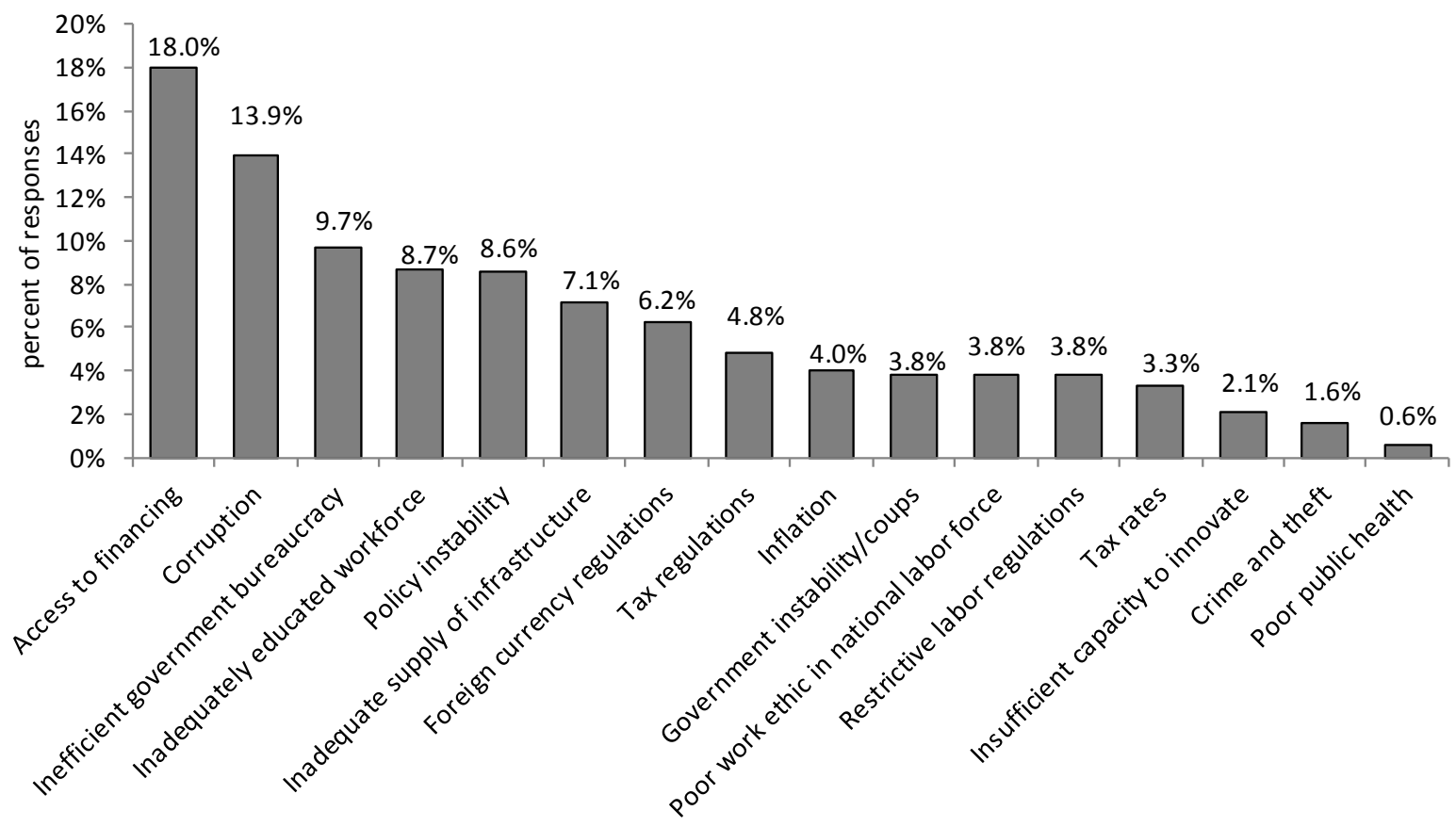

Note: From the list of factors above, respondents were asked to select the five most problematic for doing business in their country and to rank them between 1 (most problematic) and 5 . The bars in the figure show the responses weighted according to their rankings.

Source: WEF (2014). 
Figure 2 Freedom House Freedom in the World compared, 2002-13

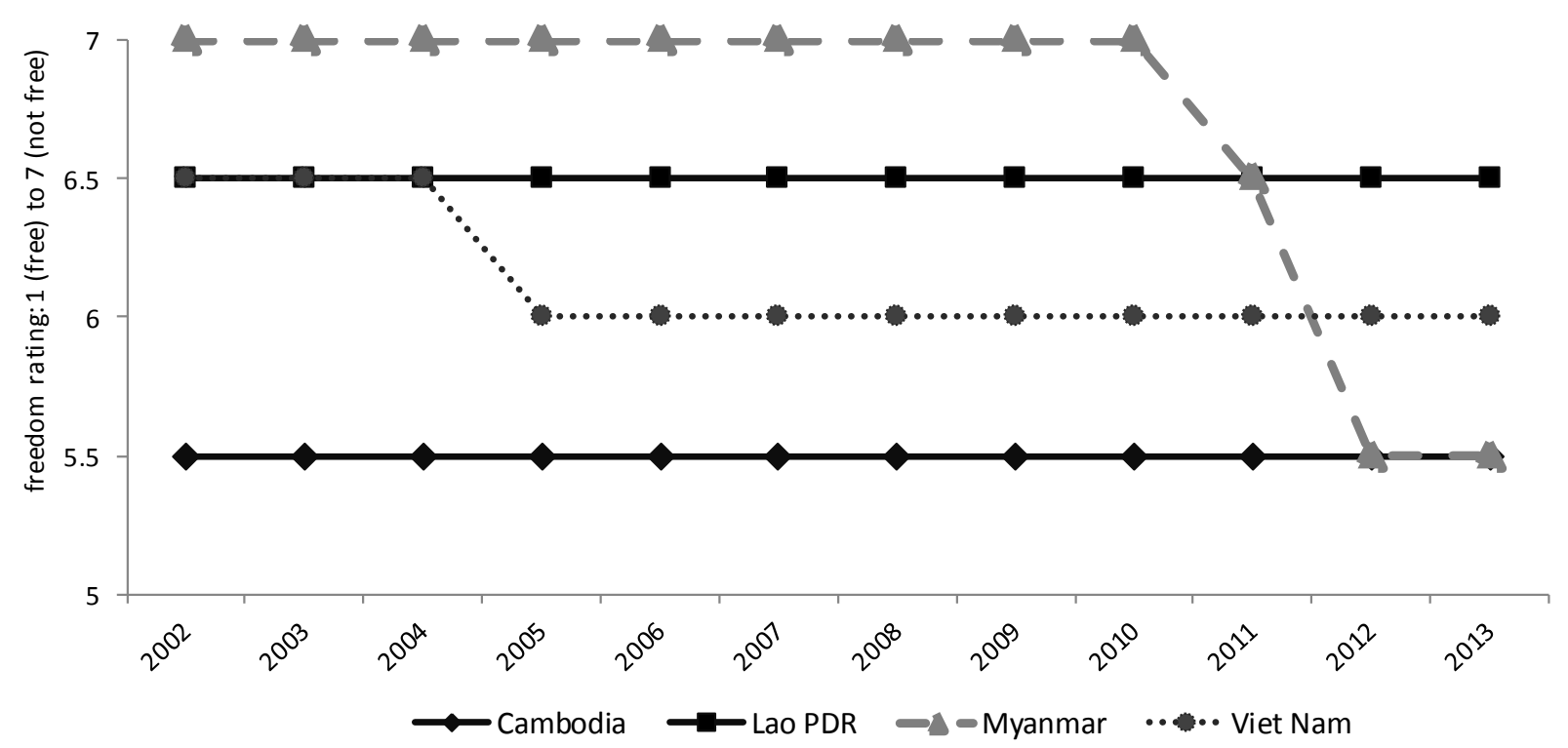

Notes: Countries with freedom ratings between 1 and 2.5 are considered "free", between 3 and 5 are considered "partly free", and 5.5 to 7 a re considered "not free." Overall score is the average of "political rights" and "civil liberties" ratings. Reported years refer to year of survey (i.e., "years covered").

Source: Freedom House (2014). 
Figure 3 Heritage Foundation Index of Economic Freedom compared, 2000-14

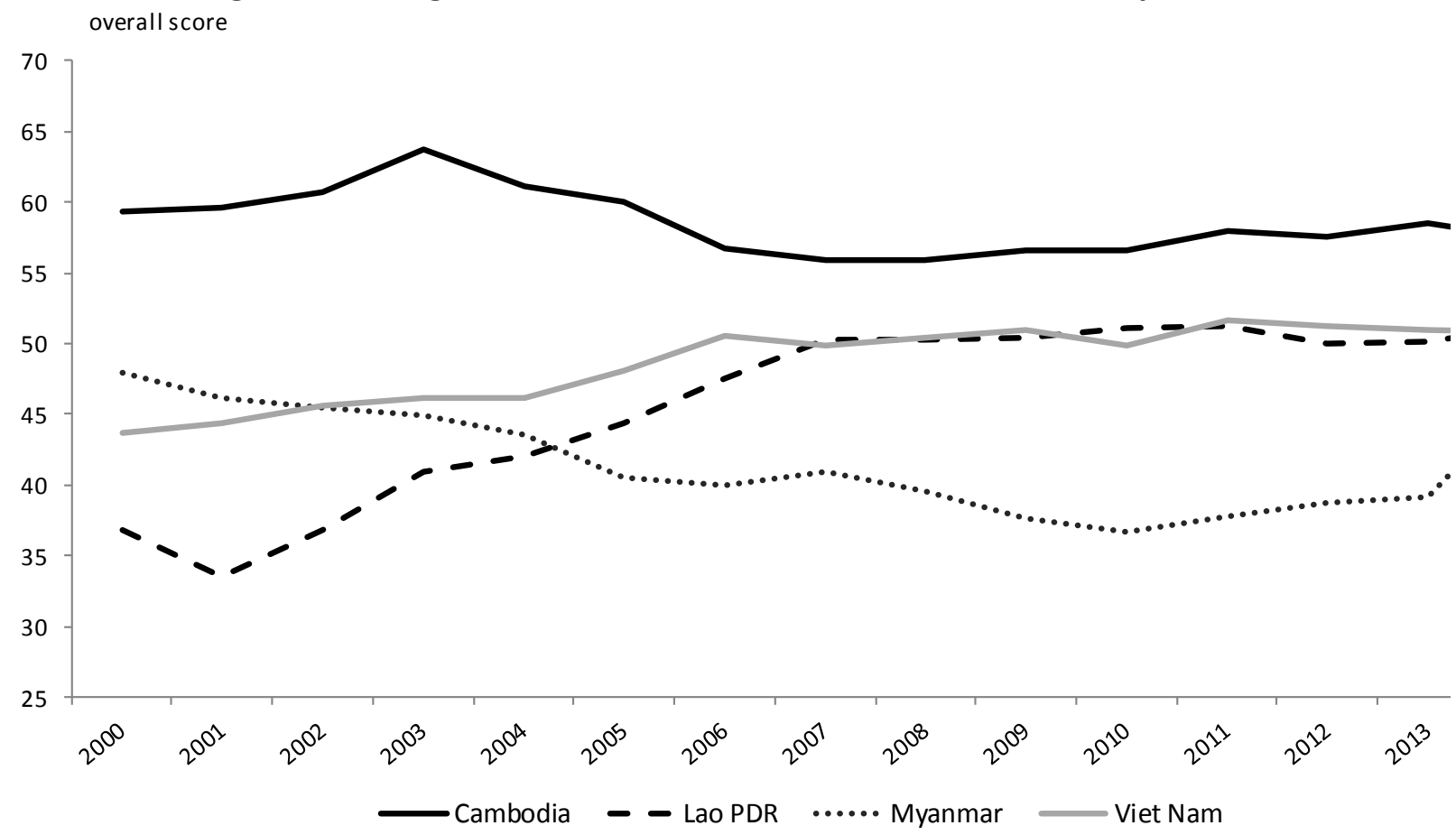

Notes: Data refer to Index of Economic Freedom composite score. Scores are on 0 to 100 scale. Source: Heritage Foundation (2014).

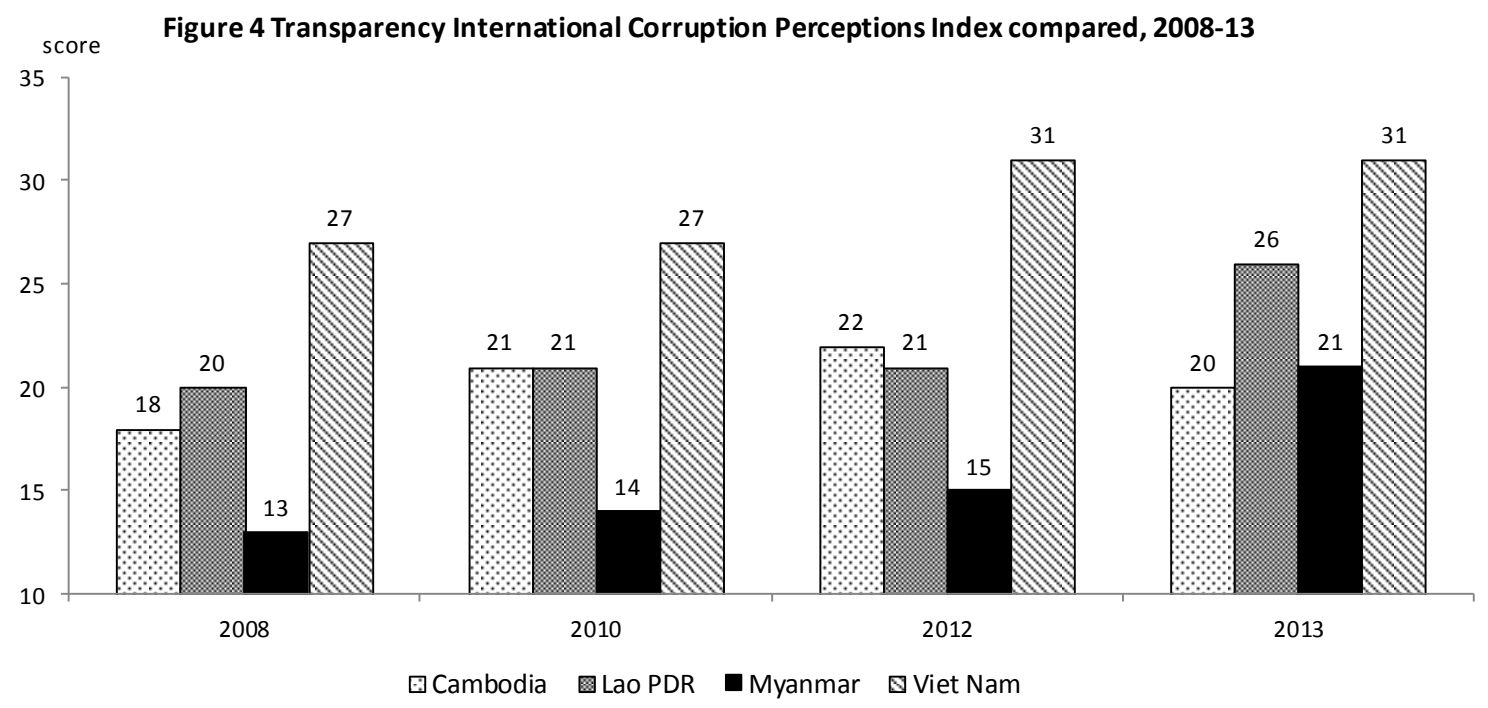

Note: Scores on a scale from 0 to 100 beginning in 2012 and 0 to 10 in prior years. All scores have been adjusted for 2012 scaling.

Source: Transparency International (2013). 


\section{Figure 5 Larger cabinets, poorer bureaucratic effectiveness}

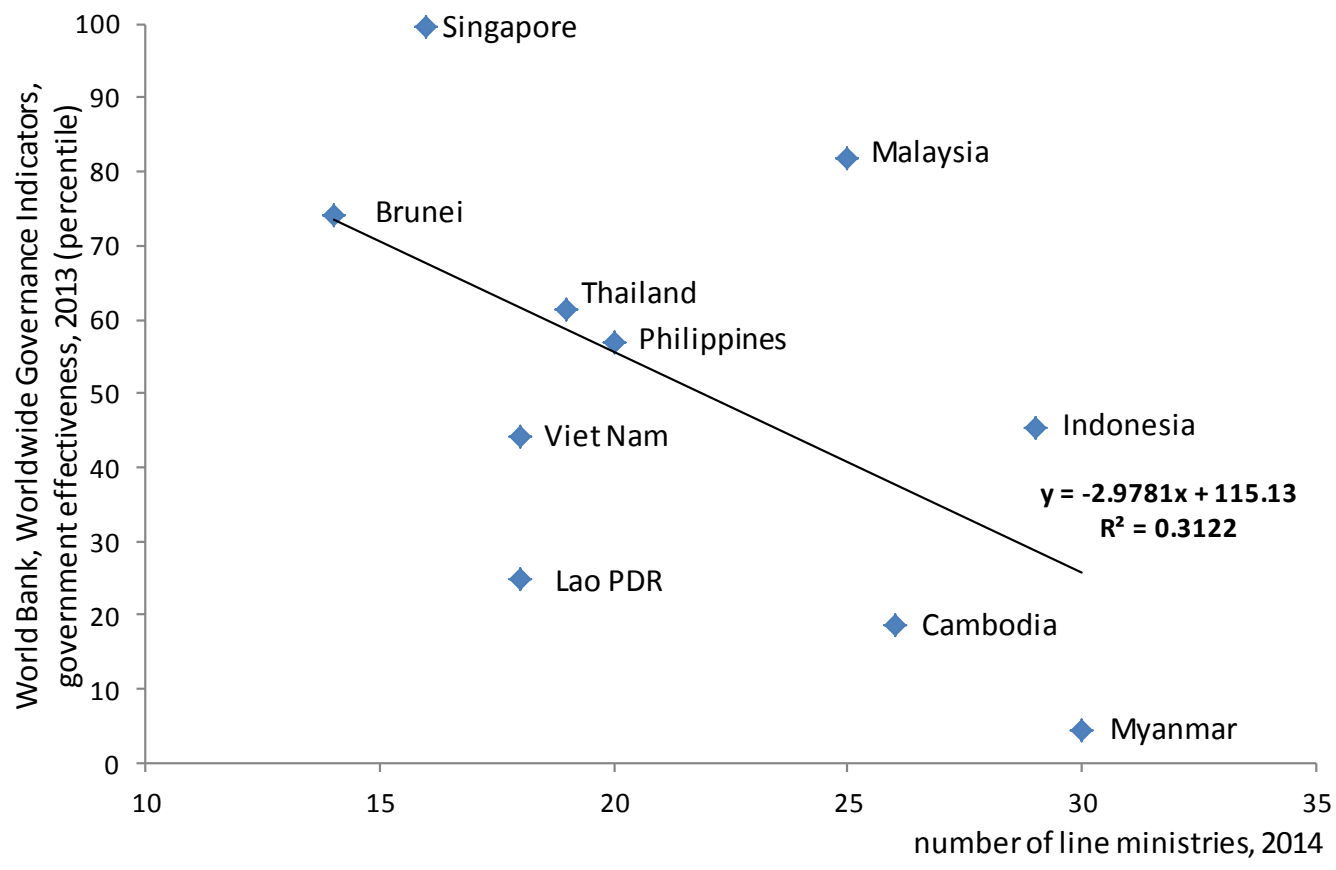

Sources: CIA (2014); World Bank (2014b). 


\begin{tabular}{|c|c|c|c|c|}
\hline \multicolumn{5}{|l|}{ Table 1 Overall governance indicators } \\
\hline Indicator & Cambodia & Lao PDR & Myanmar & Viet Nam \\
\hline $\begin{array}{l}\text { World Economic Forum, Global } \\
\text { Competitiveness Index: Overall } \\
\text { rank (2014-2015 edition) }\end{array}$ & $95 / 144$ & $93 / 144$ & 134 / 144 & $68 / 144$ \\
\hline Percentile rank & $34.2 \%$ & $35.6 \%$ & $6.9 \%$ & $53.1 \%$ \\
\hline $\begin{array}{l}\text { World Bank, Ease of Doing Business: } \\
\text { Overall rank (2015 edition) }\end{array}$ & $135 / 189$ & $148 / 189$ & 177 / 189 & $78 / 189$ \\
\hline Percentile rank & $28.7 \%$ & $21.8 \%$ & $6.3 \%$ & $59.0 \%$ \\
\hline $\begin{array}{l}\text { World Bank, Worldwide } \\
\text { Governance Indicators: } \\
\text { Government effectiveness rank } \\
(2012)\end{array}$ & $164 / 210$ & $166 / 210$ & $202 / 210$ & $117 / 210$ \\
\hline Percentile rank & $22.0 \%$ & $21.0 \%$ & $3.8 \%$ & $44.4 \%$ \\
\hline $\begin{array}{l}\text { Freedom House, Freedom in the } \\
\text { World: Overall rank ( } 2014 \text { edition) }\end{array}$ & $147 / 182$ & $177 / 182$ & 147 / 182 & $165 / 182$ \\
\hline Percentile rank & $14.2 \%$ & $5.2 \%$ & $14.2 \%$ & $7.8 \%$ \\
\hline $\begin{array}{l}\text { Heritage Foundation, Index of } \\
\text { Economic Freedom: Overall rank } \\
(2014)\end{array}$ & $108 / 178$ & $144 / 178$ & 162 / 178 & $147 / 178$ \\
\hline Percentile rank & $39.5 \%$ & $19.2 \%$ & $9.0 \%$ & $17.5 \%$ \\
\hline
\end{tabular}

Note: In some cases, rankings/percentiles have been slightly altered to account for ties with other countries. Sources: Freedom House (2014), Heritage Foundation (2014), World Bank (2013b, 2014a), WEF (2014). 


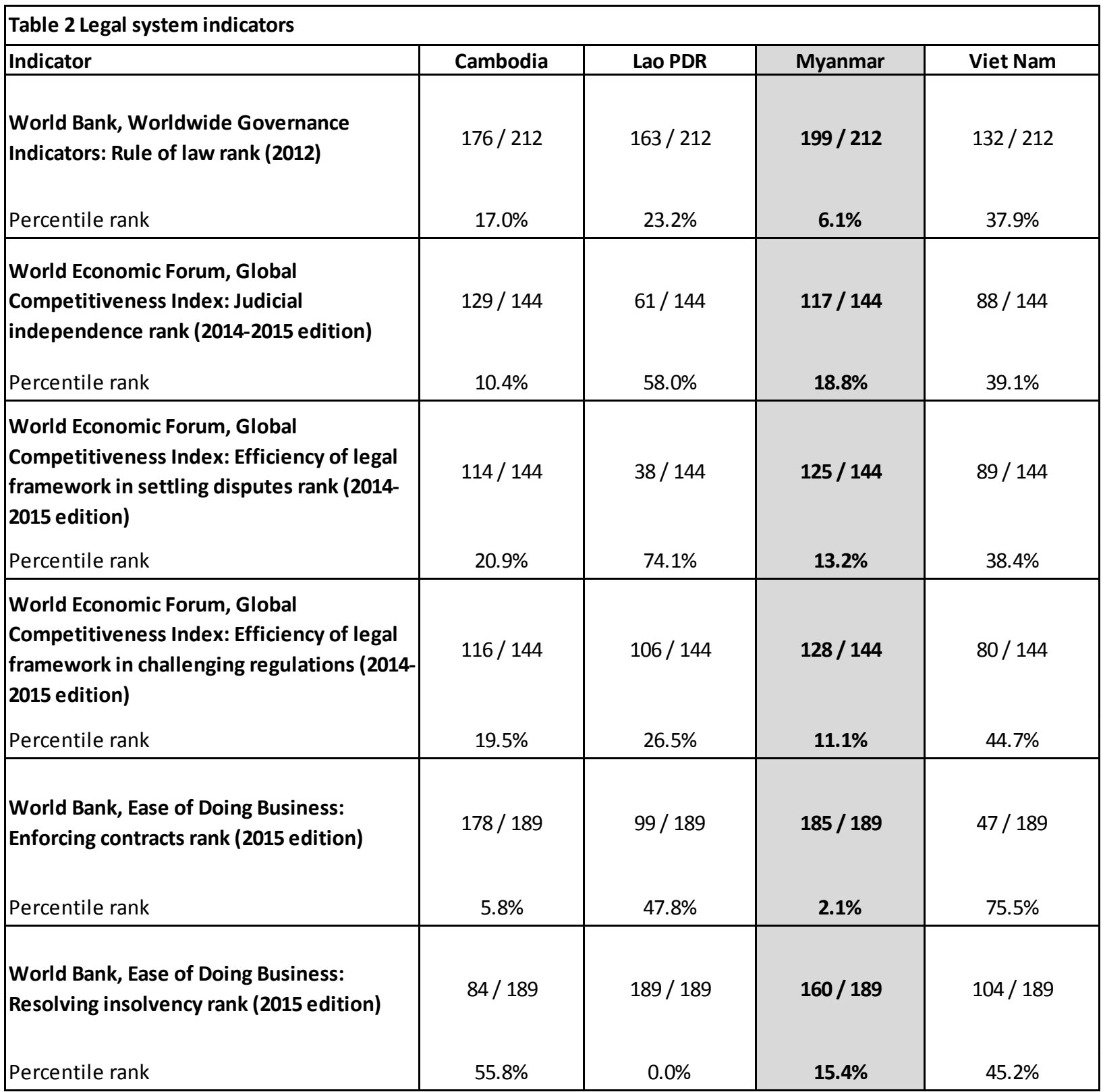

Note: In some cases, rankings/percentiles have been slightly altered to account for ties with other countries Sources: World Bank (2013b, 2014a), WEF (2014). 


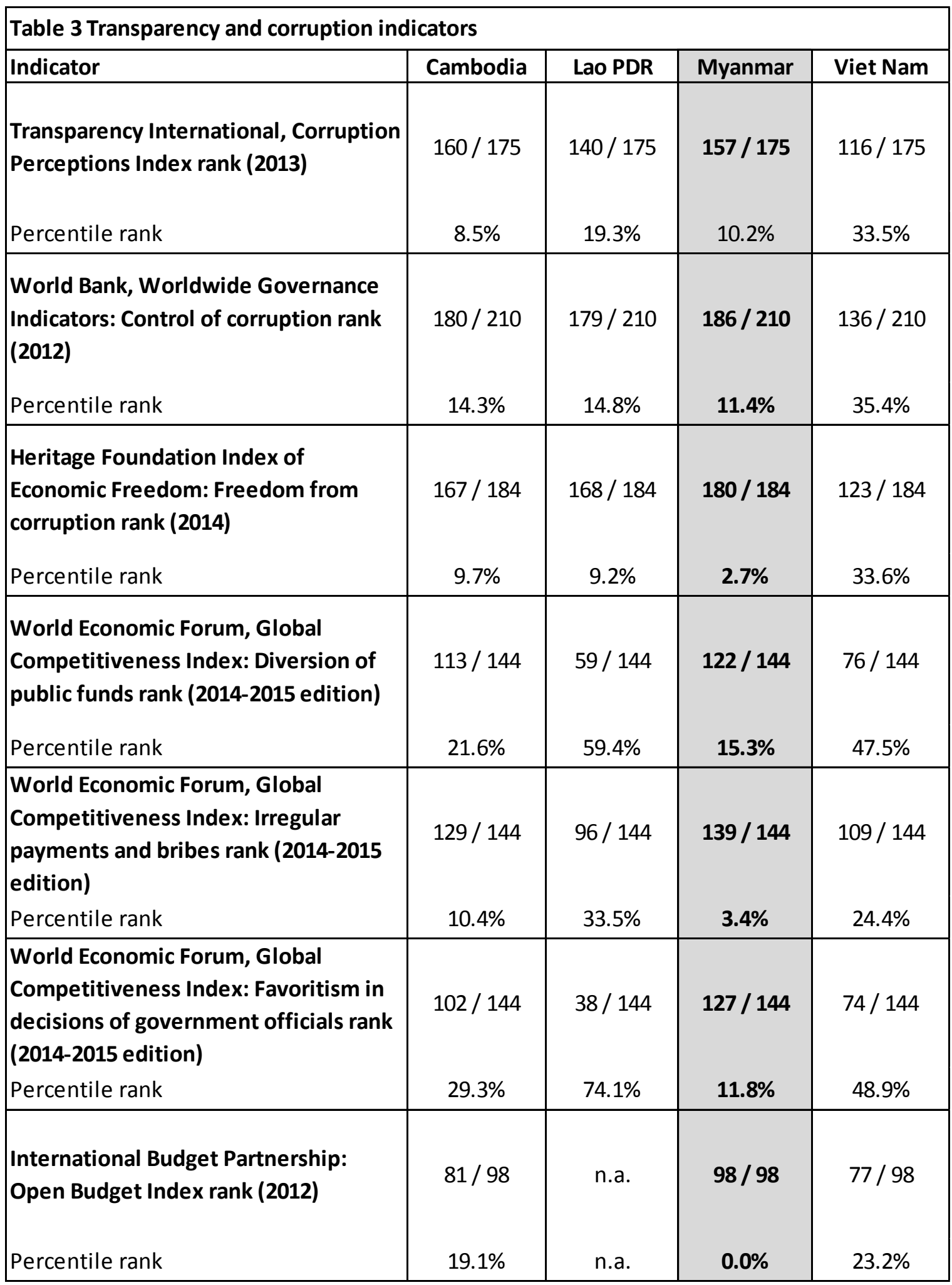

n.a. = not available

Sources: Heritage Foundation (2014), International Budget Partnership (2013), Transparency International (2013), World Bank (2013b), WEF (2014). 